\title{
Catalytic Hydrogenation of Sorbic Acid using Pyrazolyl Palladium(II) and Nickel(II) Complexes as Precatalysts
}

\author{
Oluwasegun E. Olaoye ${ }^{a} \mathbb{I D}^{\S}$, Olayinka Oyetunji, ${ }^{\mathrm{a},}$, Banothile C.E. Makhubela ${ }^{\mathrm{b}}$, \\ Apollinaire Muyaneza ${ }^{\mathrm{a}, \mathrm{d}}$, Gopendra Kumar and James Darkwa ${ }^{\mathrm{b}, \mathrm{c}, \mathrm{t}}$ \\ ${ }^{a}$ Department of Chemistry, University of Botswana, Private Bag UB 00704, Gaborone, Botswana. \\ ${ }^{b}$ Department of Chemical Sciences, University of Johannesburg, Kingsway Campus, Auckland Park, 2006, South Africa. \\ ${ }^{c}$ Botswana Institute for Technology Research and Innovation, Machel Drive, Gaborone, Botswana. \\ ${ }^{d}$ CREDERE Associates, LLC, 776 Main Street, Westbrook, ME 04092, USA. \\ Received 6 March 2020, revised 31 December 2020, accepted 20 January 2021
}

\begin{abstract}
We have prepared several pyrazolyl palladium and nickel complexes ([(L1) $\left.\mathrm{PdCl}_{2}\right](\mathbf{1}),\left[\left(\mathbf{L 2}^{2}\right) \mathrm{PdCl}_{2}\right](\mathbf{2}),\left[(\mathbf{L} 3) \mathrm{PdCl}_{2}\right](3),[(\mathbf{L} 1)$ $\left.\mathrm{NiBr}_{2}\right](4),\left[(\mathbf{L 2}) \mathrm{NiBr}_{2}\right](5)$ and [(L3) $\left.\left.\mathrm{NiBr}_{2}\right](6)\right)$ by reacting 3,5-dimethyl-1H-pyrazole (L1), 3,5-di-tert-butyl-1H-pyrazole (L2) and 5 -ferrocenyl- $1 \mathrm{H}$-pyrazole(L3) with $\left[\mathrm{PdCl}_{2}(\mathrm{NCMe})_{2}\right]$ or $\left[\mathrm{NiBr}_{2}(\mathrm{DME})\right]$ to afford mononuclear palladium and nickel complexes, respectively. These complexes were then investigated as pre-catalysts in the hydrogenation of 2,4-hexadienoic acid (sorbic acid). The active catalysts from these complexes demonstrate significant activities under mild experimental conditions. Additionally, the active catalysts show that the hydrogenation of sorbic acid proceeds in a sequential manner, where the less hindered $\mathrm{C}=\mathrm{C}$ bond (4-hexenoic acid) is preferentially reduced over the more hindered $\mathrm{C}=\mathrm{C}$ bond (2-hexenoic acid).
\end{abstract}

KEYWORDS

Pyrazolyl catalysts, sorbic acid, hydrogenation, selectivity.

\section{Introduction}

Hydrogenation of $\alpha, \beta$-unsaturated compounds has been widely employed in the vitamins, fragrances, pharmaceuticals, petrochemicals, agrochemicals, and cosmetics industries. ${ }^{1}$ One of the extensively used transition metal catalysts in these hydrogenation reactions is chlorotris(triphenylphosphine)rhodium(I), $\left[\mathrm{RhCl}\left(\mathrm{PPh}_{3}\right)_{3}\right]^{2,3}$ The catalyst, $\mathrm{RhCl}\left(\mathrm{PPh}_{3}\right)_{3}$, catalyzes the chemo-specific hydrogenation of $\mathrm{C}=\mathrm{C}$ bonds in the presence of other easily reduced groups, like nitro $\left(\mathrm{NO}_{2}\right)$ or carbonyl $(\mathrm{CHO})$, as well as terminal alkenes even when the substrate has internal alkenes. ${ }^{2,3}$ Other transition metals complexes have been extensively studied as heterogeneous and homogeneous catalysts in the catalytic hydrogenation of olefins and $\alpha, \beta$-unsaturated compounds. Among these metal complexes are ruthenium, ${ }^{4,5}$ rhodium, ${ }^{6}$ iridium, ${ }^{7}$ and platinum. ${ }^{8}$ However, nicke ${ }^{9}$ and palladium $^{10}$ complexes have in recent times gained considerable attention as efficient catalysts in hydrogenation reactions. Shevlin et al. described the first homogeneous nickel-catalyzed asymmetric hydrogenation of $\alpha, \beta$-unsaturated esters, using molecular hydrogen, that gave high yield and high enantioselective products. ${ }^{11}$ Apart from the good reactivity and selectivity of the nickel catalysts, ligand manipulation makes them attractive for homogeneous catalysts. Nickel catalysts are cheap and cost-effective.

On the other hand, palladium catalysts are more expensive but exhibit superior catalytic and selectivity properties in the hydrogenation of unsaturated compounds. ${ }^{12}$ For example, $\mathrm{P}^{\wedge} \mathrm{C}^{\wedge} \mathrm{P}$ palladium pincer complexes are highly active catalysts for the chemo-selective transfer hydrogenation of $\alpha, \beta$-unsaturated ketones. ${ }^{13}$ These highly reactive and selective palladium pincer complexes afforded saturated ketones from $\alpha$-enones. ${ }^{13}$ Similarly, Bacci et al. reported hydrazinic-phosphine $\left(\mathrm{P}^{\wedge} \mathrm{N}\right)$ palla-

* To whom correspondence should be addressed.

E-mail: O.O., oyetunji@ub.ac.bw / J.D., jdarkwa@bitri.co.bw
dium(II) complexes as efficient catalysts for $\mathrm{C}=\mathrm{C}$ bonds hydrogenation under mild experimental condition. ${ }^{14}$

However, because phosphines are sensitive to air and moisture, ${ }^{15}$ palladium complexes with nitrogen-donor ligands are emerging as an alternative to phosphorus-donor palladium complexes as hydrogenation catalysts. For example, \{bis(arylimino)acenaphthene\}-palladium(0) complexes are known to be efficient and highly chemo-selective in the hydrogenation of $\mathrm{C}=\mathrm{C}$ bonds of $\alpha, \beta$-unsaturated aldehydes. ${ }^{16}$ But despite numerous nitrogen-donor nickel(II) and palladium(II) applications in catalysis, little work has been reported on their catalytic properties in the hydrogenation of $\alpha, \beta$-unsaturated compounds.

In this study, we report on pyrazolyl nickel(II) and palladium(II) complexes as catalysts for the hydrogenation of 2,4-hexanoic acid (sorbic acid), which is an $\alpha, \beta$-unsaturated acid. This study forms part of a bigger project on partial hydrogenation of biofuels from triglycerides.

\section{Experimental}

\subsection{General Information}

Standard Schlenk and vacuum line techniques were used to handle all air and moisture sensitive compounds. All chemicals and gases were procured from the sources indicated for each one of them and include their purity: Gases - argon and hydrogen (>99\% purity) from Afrox (South Africa); solvents and reagents from Sigma Aldrich - Ethylformate $(97 \%)$, acetic anhydride (99\%), ferrocene (98\% hydrazine monohydrate $(98 \%)$, hydrazine dihydrochloride (98\%), (ethyleneglycoldimethylether) nickel(II) bromide (98\%), formic acid (95\%) and 3,5-dimethyl1 H-pyrazole (L1) $(99 \%)$.

Literature procedures were used to prepare the following starting materials: 3,5-di-tert-butyl-1H-pyrazole (L2) $)^{17}$, 3-ferrocenyl-1H-pyrazole $(\mathbf{L} 3)^{18}$ and $\left[\mathrm{PdCl}_{2}(\mathrm{NCMe})_{2}\right]^{19}$ as well as 
dibromo $\{$ bis-3,5-dimethyl-1H-pyrazole $\}$ nickel(II) (4) and dibromo $\{$ bis-3,5-tert-butyl-1H-pyrazole $\}$ nickel(II) $(5)^{20(a)}$ with L1 and L2, respectively.

NMR spectra were recorded in $\mathrm{CDCl}_{3}$ as solvent using Bruker 400 Ultra-shield $\mathrm{MHz}$ NMR spectrometer at $400 \mathrm{MHz}$ for the ${ }^{1} \mathrm{H}$ spectra and $100 \mathrm{MHz}$ for the ${ }^{13} \mathrm{C}\left\{{ }^{1} \mathrm{H}\right\}$ spectra. Infrared spectra were recorded on a Perkin Elmer FT-IR Spectrum BX II fitted with an ATR probe. Melting points were determined using Gallenkamp Digital Melting-point Apparatus 5A 6797, while elemental analysis data were collected on a Thermos Scientific FLASH 2000 CHNS-O Analyser. Mass spectra were similarly collected on a Waters API Quattro Micro Triple Quadrupole electrospray ionization mass spectrometer.

All hydrogenation reactions were carried out in PPV-CTR01CE (Eyela, Japan) high-pressure autoclave reactor with a stirring pact, heating and cooling systems. ${ }^{20(b)}$ The course of hydrogenation reactions involving palladium catalysts were followed by ${ }^{1} \mathrm{H}$ NMR spectroscopy, using dioxane as an internal standard, which was used to determine percentage conversions. The conversions were determined using the diagnostic peaks, following the integrations of the products from the hydrogenation reaction compared to the integration of dioxane.

\subsection{Syntheses of bis(Pyrazole)palladium(II) and Nickel(II) Complexes}

\subsubsection{Synthesis of Dichloro $\{$ bis-3,5-dimethyl-1H-pyrazole $\}$ palladium(II) (1)}

L1 $(74 \mathrm{mg}, 0.771 \mathrm{mmol})$ and $\left[\mathrm{PdCl}_{2}(\mathrm{NCMe})_{2}\right](100 \mathrm{mg}$ $0.386 \mathrm{mmol})$ were dissolved in $\mathrm{CH}_{2} \mathrm{Cl}_{2}(20 \mathrm{~mL})$, and then stirred continuously at room temperature for $24 \mathrm{~h}$ to produce an orange solution. This was followed by in vacuo removal of the solvent to produce compound 1 as an orange solid. Yield: $150 \mathrm{mg}(84 \%)$; melting point: $250-252{ }^{\circ} \mathrm{C}$ (decomposes without melting). ${ }^{1} \mathrm{H}$ NMR $\left(400 \mathrm{MHz}, \mathrm{CDCl}_{3}\right):{ }^{1} \mathrm{H}$ NMR $\left(\mathrm{CDCl}_{3}\right): \delta(\mathrm{ppm}) 1.89(\mathrm{~s}$, $\left.2 \times 3 \mathrm{H}, 2 \times \underline{\mathrm{C}}_{3}\right) ; 2.65\left(\mathrm{~s}, 2 \times 3 \mathrm{H}, 2 \times \mathrm{CH}_{3}\right) ; 5.67$ (s, $\left.1 \mathrm{H}, 4-\underline{\mathrm{H}} \mathrm{pz}\right) ; 11.82(\mathrm{~s}$, $1 \mathrm{H}, \mathrm{N}-\underline{\mathrm{H}}$ pz) (Fig. SI-8). ${ }^{13} \mathrm{C}\left\{{ }^{1} \mathrm{H}\right\}$ NMR $\left(100 \mathrm{MHz}, \mathrm{CDCl}_{3}\right)$ (ppm): $151.6\left(\mathrm{C}_{\mathrm{d}}-\underline{\mathrm{C}}\right) ; 143.0\left(\mathrm{C}_{\mathrm{e}}-\underline{\mathrm{C}}\right) ; 105.6\left(\mathrm{C}_{\mathrm{c}}-\underline{\mathrm{CH}}\right) ; 14.9\left(\mathrm{C}_{\mathrm{b}}-\underline{\mathrm{CH}}_{3}\right) ; 10.3$ $\left(\mathrm{C}_{\mathrm{a}}-\mathrm{CH}_{3}\right)$ (Fig. SI-9). Elemental analysis; Anal. calcd. for $\mathrm{C}_{10} \mathrm{H}_{16} \mathrm{Cl}_{2} \mathrm{~N}_{4} \mathrm{Pd}: \mathrm{C}, 32.50 \% ; \mathrm{H}, 4.36 \% ; \mathrm{N}, 15.16 \%$. Found: C, $32.92 \% ; \mathrm{H}, 4.34 \% ; \mathrm{N}, 15.06 \%$.

\subsubsection{Synthesis of Dichloro $\{$ bis-3,5-tert-buytl-1H-pyrazole $\}$ palladium(II) (2)}

L2 (139 mg, $0.771 \mathrm{mmol})$ and $\left[\mathrm{PdCl}_{2}(\mathrm{NCMe})_{2}\right](100 \mathrm{mg}$, $0.386 \mathrm{mmol})$ were dissolved in $\mathrm{CH}_{2} \mathrm{Cl}_{2}(20 \mathrm{~mL})$, and then stirred continuously at room temperature for $24 \mathrm{~h}$, affording an orange solution. This was followed by in vacuo removal of the solvent to produce compound 2 as a yellowish-orange solid. Yield: $150 \mathrm{mg}$ (72\%); melting point: $220-224^{\circ} \mathrm{C}$ (decompose without melting). ${ }^{1} \mathrm{HNMR}\left(400 \mathrm{MHz}, \mathrm{CDCl}_{3}\right): \delta(\mathrm{ppm}) 1.00\left(\mathrm{~s}, 2 \times 9 \mathrm{H}, 6 \times \mathrm{xC}_{3}\right) ; 1.76(\mathrm{~s}$, $\left.2 \times 9 \mathrm{H}, 6 \times \underline{\mathrm{CH}}_{3}\right) ; 5.82$ (s, IH, 4- $\left.\underline{\mathrm{H}} \mathrm{pz}\right) ; 11.65$ (s, 1H, N- $\underline{\mathrm{H}}$ ) (Fig. SI-10). ${ }^{13} \mathrm{C}\left\{{ }^{1} \mathrm{H}\right\}$ NMR $\left(100 \mathrm{MHz}, \mathrm{CDCl}_{3}\right)(\mathrm{ppm}): 165.0\left(\mathrm{C}_{\mathrm{f}}-\underline{\mathrm{C}}\right) ; 156.7$ $\left(\mathrm{C}_{\mathrm{e}}-\mathrm{C}\right) ; 101.7\left(\mathrm{C}_{\mathrm{d}}-\mathrm{C}\right) ; 32.4\left(\mathrm{C}_{\mathrm{c}}-\mathrm{C}\right) ; 31.1\left(\mathrm{C}_{\mathrm{b}}-\underline{\mathrm{C}}\right) ; 30.0\left(\mathrm{C}_{\mathrm{a}}-\mathrm{CH}_{3}\right)$ (Fig. SI-11). Elemental analysis; Anal. calcd. for $\mathrm{C}_{22} \mathrm{H}_{40} \mathrm{Cl}_{2} \mathrm{~N}_{4} \mathrm{Pd}$ : C, $49.12 \% ; \mathrm{H}, 7.50 \%$; N $10.42 \%$. Found C: $48.92 \% ; \mathrm{H}, 7.16 \%, \mathrm{~N}$, $10.00 \%$.

\subsubsection{Synthesis of Dichloro $\{$ bis-5-ferrocenyl-1H-pyrazole $\}$ palladium(II) (3)}

L3 (90 mg, $0.3571 \mathrm{mmol})$ and $\left[\mathrm{PdCl}_{2}(\mathrm{NCMe})_{2}\right](46 \mathrm{mg}$, $0.1785 \mathrm{mmol})$ were dissolved in $\mathrm{CH}_{2} \mathrm{Cl}_{2}(20 \mathrm{~mL})$, followed by continuous stirring at room temperature for $24 \mathrm{~h}$ to produce an orange solution. Upon removal of the solvent in vacuo, compound 3 was obtained as a yellow-orange solid. Yield: $120 \mathrm{mg}$ (49\%); melting point: $230-232{ }^{\circ} \mathrm{C}$ (decompose without melting). ${ }^{1} \mathrm{H} \mathrm{NMR}\left(400 \mathrm{MHz}, \mathrm{CDCl}_{3}\right): \delta(\mathrm{ppm}) 7.89(\mathrm{~s}, 1 \mathrm{H}, \mathrm{pz}) ; 6.15$ $(\mathrm{s}, 1 \mathrm{H}, p \mathrm{z}) ; 4.57\left(\mathrm{~s}, 2 \mathrm{H}, \eta^{5}-\mathrm{C}_{5} \underline{\mathrm{H}}_{5}\right) ; 4.34\left(\mathrm{~s}, 2 \mathrm{H}, \eta^{5}-\mathrm{C}_{5} \underline{\mathrm{H}}_{5}\right) ; 4.14(\mathrm{~s}, 5 \mathrm{H}$, $\left.\eta^{5}-\mathrm{C}_{5} \underline{\mathrm{H}}_{5}\right) ; 11.53(\mathrm{~s}, 1 \mathrm{H}, \mathrm{N}-\underline{\mathrm{H}})$ (Fig. SI-12). ${ }^{13} \mathrm{C}\left\{{ }^{1} \mathrm{H}\right\} \mathrm{NMR}(100 \mathrm{MHz}$, $\left.\mathrm{CDCl}_{3}\right)(\mathrm{ppm}): 144.8\left(\mathrm{C}_{\mathrm{d}}-\mathrm{CH}\right) ; 142.7\left(\mathrm{C}_{\mathrm{c}}-\mathrm{CH}\right) ; 103.7\left(\mathrm{C}_{\mathrm{b}}-\mathrm{C}\right) ; 71.6$, 70.3, $67.0\left(\eta^{5}-\mathrm{C}_{2} \mathrm{H}_{5}\right)$ (Fig. SI-13). Elemental analysis; Anal. calcd. for $\mathrm{C}_{26} \mathrm{H}_{24} \mathrm{Cl}_{2} \mathrm{Fe}_{2} \mathrm{~N}_{4} \mathrm{Pd}$ : C, $45.82 \%$; $\mathrm{H}, 3.55 \%$; N, $8.22 \%$. Found C, $45.76 \% ; \mathrm{H}, 3.46 \% ; \mathrm{N}, 8.27 \%$.

\subsubsection{Synthesis of Dibromo $\{$ bis-5-ferrocenyl-1H-pyrazole $\}$ nickel(II) (6)}

L3 (70 mg, $0.2778 \mathrm{mmol})$ and $\left[\mathrm{NiBr}_{2}\right.$ (DME)] (45 mg, $0.1388 \mathrm{mmol}$ ) were dissolved in $20 \mathrm{~mL} \mathrm{CH}_{2} \mathrm{Cl}_{2}$, and then stirred continuously at room temperature for $24 \mathrm{~h}$ producing an orange-brown solution. The solution was then concentrated and dried under vacuum for $6 \mathrm{~h}$ to yield complex 6. Yield: $70 \mathrm{mg}$ (70 \%); melting point: $210-212{ }^{\circ} \mathrm{C}$; IR $\left(v_{\max } / \mathrm{cm}^{-1}\right)$ : $3218(\mathrm{~N}-\mathrm{H})$; $1623(\mathrm{C}=\mathrm{C}) ; 1589(\mathrm{C}=\mathrm{N})$. Elemental analysis; Anal. calcd. for $\mathrm{C}_{26} \mathrm{H}_{24} \mathrm{Br}_{2} \mathrm{Fe}_{2} \mathrm{~N}_{4} \mathrm{Ni}$ : C, $43.21 \%$; $3.35 \%$;, $7.75 \%$. Found: C, $42.95 \% ; \mathrm{H}, 3.27 \%$; N, $7.63 \%$.

\subsection{Molecular Structure Determination}

A mixture of $\mathrm{CH}_{2} \mathrm{Cl}_{2}(0.5 \mathrm{~mL})$ and $\mathrm{n}$-hexane $(0.1 \mathrm{~mL})$ for 2 or $\mathrm{CHCl}_{3}(0.5 \mathrm{~mL})$ and $\mathrm{n}$-hexane $(0.1 \mathrm{~mL})$ for 3 was used to obtain single crystals that were subsequently used for $\mathrm{X}$-ray diffraction data collection for molecular structure determination.

Crystal data were collected using Bruker APEX-II CCD diffractometer with $\mathrm{MoK} \alpha(\lambda=0.71073 \AA)$. The diffractometer to crystal distance was $4.00 \mathrm{~cm}$, and all crystal data collected at $100 \mathrm{~K}$. Data reduction measurement was performed using SAINT $+{ }^{21}$ and the intensity correction for absorption using SADABS. ${ }^{21}$ Refinement of structures, with least square minimization, was performed using the SHELXT ${ }^{22}$ and SHELXL ${ }^{23}$ software packages. All non-hydrogen atoms were refined with anisotropic displacement coefficients and placed in geometrically idealized positions, and constrained to ride on their parent atoms with relative isotropic coefficients. ${ }^{22,23}$

\subsection{General Procedure for Hydrogenation Reactions}

\subsubsection{Hydrogenation with Molecular Hydrogen}

Hydrogenation reactions using molecular hydrogen were studied in reactors with stainless steel vessels coupled with magnetic stirrers. In a typical experiment, the contents of the vessel consist of sorbic acid $(0.5 \mathrm{mmol})$, catalyst $(2.5 \mu \mathrm{mol}$, $0.5 \mathrm{~mol} \%)$, hydrogen gas (5 bar) and methanol $(5 \mathrm{~mL})$. The solution mixture was purged twice with nitrogen gas, followed by the introduction of hydrogen gas ( 5 bar) and constant stirring of the mixture at $40{ }^{\circ} \mathrm{C}$ for $2 \mathrm{~h}$. At the end of the reaction period, the reaction vessel was cooled, and the excess pressure generated was vented off slowly. The resulting hydrogenation products were withdrawn and filtered with MS nylon syringe filter $(0.22 \mu \mathrm{m}, 13 \mathrm{~mm})$. Their \% conversions were then determined by ${ }^{1} \mathrm{H}$ NMR spectroscopy, using dioxane as an internal standard.

\subsubsection{Hydrogenation with Formic Acid}

In a typical experiment, sorbic acid $(0.5 \mathrm{mmol})$, catalyst $(2.5 \mu \mathrm{mol}, 0.5 \mathrm{~mol} \%)$ formic acid $(20 \mathrm{mmol}), \mathrm{KOH}(4 \mathrm{mmol})$ and methanol $(5 \mathrm{~mL})$ were introduced into the reactor vessel. The solution mixture was purged twice with nitrogen gas, followed by stirring at $90^{\circ} \mathrm{C}$ for $12 \mathrm{~h}$. At the end of the reaction period, the reaction vessel was cooled, and the excess pressure generated 
was vented off slowly. The hydrogenation products were drawn out of the reactor vessel, filtered using $\mathrm{MS}^{\circledR}$ nylon syringe filter $(0.22 \mu \mathrm{m}, 13 \mathrm{~mm})$ and their \% conversions determined by ${ }^{1} \mathrm{H}$ NMR spectroscopy, using dioxane as an internal standard.

\section{Result and Discussion}

\subsection{Synthesis of Palladium and Nickel Complexes.}

The pre-catalysts 1-6 were synthesized with compounds L1-L3 and the corresponding metal precursors, as shown in Scheme 1. Characterization of the palladium complexes was achieved using a combination of ${ }^{1} \mathrm{H}$ NMR, IR, mass spectrometry and elemental analysis. The structures of the two new complexes, 2 and 3, were confirmed by single-crystal X-ray crystallography. Characterization of the nickel complexes, on the other hand, was carried out using mainly IR spectroscopy and elemental analysis. The structure of one of them, 4, was confirmed by single-crystal X-ray crystallography showing a structure result similar to that reported earlier. ${ }^{20}$

Characteristic chemical shifts of the pyrazolyl nitrogen protons $(\mathrm{N}-\mathrm{H})$ confirmed the successful ligand complexations. For instance, there was a downfield shift in the position of N-H proton from $11.20 \mathrm{ppm}$ to $11.82 \mathrm{ppm}$ in $\mathbf{1}$; from $10.19 \mathrm{ppm}$ to 11.65 in 2; and from $10.62 \mathrm{ppm}$ to 11.53 in 3 . All other spectroscopic data were as expected and similar to those previously reported for $\mathbf{1}^{24}, \mathbf{2}^{24}$, and $3^{25}$.

\subsection{Molecular Structures of 2 and 3}

Slow evaporation of solutions of 2 in $\mathrm{CHCl}_{3}$ and 3 in $\mathrm{CH}_{2} \mathrm{Cl}_{2}$ at room temperature produced orange crystals good enough for single-crystal X-ray crystallographic analysis. The crystals and structure refinement information are shown in Table 1, and the molecular structures in Figs. 1 and 2. Complexes $\mathbf{2}$ and $\mathbf{3}$ crystallized in C2/c and P-1 space groups, respectively. Figures 1 and 2 show that the pyrazole nitrogen atom is coordinated to the palladium in square planar geometries. However, the ${ }^{t} B u$ groups in 2 are disordered. This disorder was handled during the refinement process by rotating the $\mathrm{H}$ atoms around the ${ }^{\mathrm{t}} \mathrm{Bu}$ axis to minimize the restraint caused by the tert-butyl groups. Selected
Table 1 Crystallographic data for complexes 2 and 3

\begin{tabular}{|c|c|c|}
\hline & 2. $\mathrm{CHCl}_{3}$ & 3. $\mathrm{CH}_{2} \mathrm{Cl}_{2}$ \\
\hline Empirical formula & $\mathrm{C}_{23} \mathrm{H}_{41} \mathrm{Cl}_{5} \mathrm{~N}_{4} \mathrm{Pd}$ & $\mathrm{C}_{27} \mathrm{H}_{26} \mathrm{Cl}_{4} \mathrm{Fe}_{2} \mathrm{~N}_{4} \mathrm{Pd}$ \\
\hline Formula weight & 657.25 & 766.16 \\
\hline Temperature/K & 99.96 & 100.02 \\
\hline Crystal system & Monoclinic & Triclinic \\
\hline Space group & $\mathrm{C} 2 / \mathrm{c}$ & P-1 \\
\hline $\mathrm{a} / \AA ̊ \AA$ & $25.066(3)$ & 13.5082(16) \\
\hline $\mathrm{b} / \AA$ & $12.2089(11)$ & $18.204(2)$ \\
\hline$c / \AA$ & 21.0499(1@8) & $24.120(3)$ \\
\hline$\alpha /^{\circ}$ & 90 & $107.316(2)$ \\
\hline$\beta /^{\circ}$ & $106.859(4)$ & $90.970(3)$ \\
\hline$\gamma /{ }^{\circ}$ & 90 & $95.614(3)$ \\
\hline Volume $/ \AA^{3}$ & $6164.9(10)$ & $5628.5(11)$ \\
\hline Z & 8 & 8 \\
\hline$\rho_{\text {cald }} / \mathrm{g} \mathrm{cm}^{-3}$ & 1.416 & 1.808 \\
\hline$\mu / \mathrm{mm}^{-1}$ & 1.054 & 2.055 \\
\hline $\mathrm{F}(000)$ & 2704.0 & 3054.0 \\
\hline Radiation & $\begin{array}{c}\operatorname{MoK} \alpha \\
(\lambda=0.71073)\end{array}$ & $\begin{array}{c}\operatorname{MoK} \alpha \\
(\lambda=0.71073)\end{array}$ \\
\hline $2 \Theta$ range for data collection ${ }^{\circ}$ & 3.744 to 49.964 & 1.77 to 50.882 \\
\hline Reflections collected & 45923 & 93054 \\
\hline Independent reflections & $\begin{aligned} 5407 \\
{\left[\mathrm{R}_{\text {int }}=0.1098\right.} \\
\left.\mathrm{R}_{\text {sigma }}=0.0691\right]\end{aligned}$ & $\begin{array}{c}20743 \\
{\left[\mathrm{R}_{\text {int }}=0.0914,\right.} \\
\left.\mathrm{R}_{\text {sigma }}=0.0926\right]\end{array}$ \\
\hline Data/restraints/parameters & $5407 / 0 / 318$ & $20743 / 0 / 1369$ \\
\hline Goodness-of-fit on $\mathrm{F}^{2}$ & 1.045 & 1.060 \\
\hline $\begin{array}{l}\text { Final R indexes } \\
{[I \geq 2 \sigma(\mathrm{I})]}\end{array}$ & $\begin{array}{c}\mathrm{R}_{1}=0.0409 \\
\mathrm{wR}_{2}=0.1011\end{array}$ & $\begin{array}{c}\mathrm{R}_{1}=0.0574 \\
\mathrm{wR}_{2}=0.1477\end{array}$ \\
\hline $\begin{array}{l}\text { Final } R \text { indexes } \\
\text { [all data] }\end{array}$ & $\begin{array}{c}\mathrm{R}_{1}=0.0474 \\
\mathrm{wR}_{2}=0.1053\end{array}$ & $\begin{array}{r}\mathrm{R}_{1}=0.0713 \\
\mathrm{wR}_{2}=0.1601\end{array}$ \\
\hline
\end{tabular}

bond distances and angles for the two palladium complexes are shown in the captions of Figs. 1 and 2. In $\mathbf{2} \cdot \mathrm{CHCl}_{3}$ the square planar geometry is distorted from $90^{\circ}$ to the following bond angles: $\mathrm{N}(1)-\mathrm{Pd}(1)-\mathrm{Cl}(1), 86.70(7) ; \mathrm{N}(1)-\mathrm{Pd}(1)-\mathrm{Cl}(2)$, 92.14(7);<smiles>[R]c1cc([R])[nH]n1</smiles>

L1: $\mathrm{R}^{\prime}=\mathrm{Me}, \mathrm{R}=\mathrm{Me}$

L2: $\mathrm{R}^{\prime}={ }^{\mathrm{t}} \mathrm{Bu}, \mathrm{R}={ }^{\mathrm{t}} \mathrm{Bu}$

L3: $\mathrm{R}^{\prime}=\mathrm{H}, \quad \mathrm{R}=$ Ferrocenyl
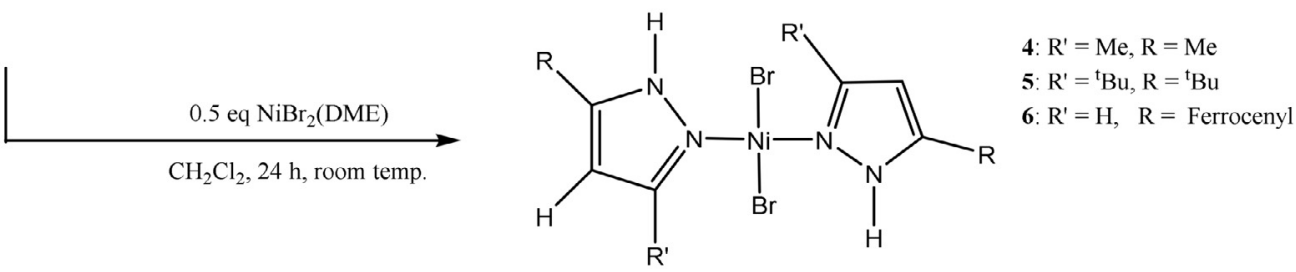

Scheme 1

Schematic illustrations of monomeric pyrazolyl palladium(II) and nickel(II) complexes. 


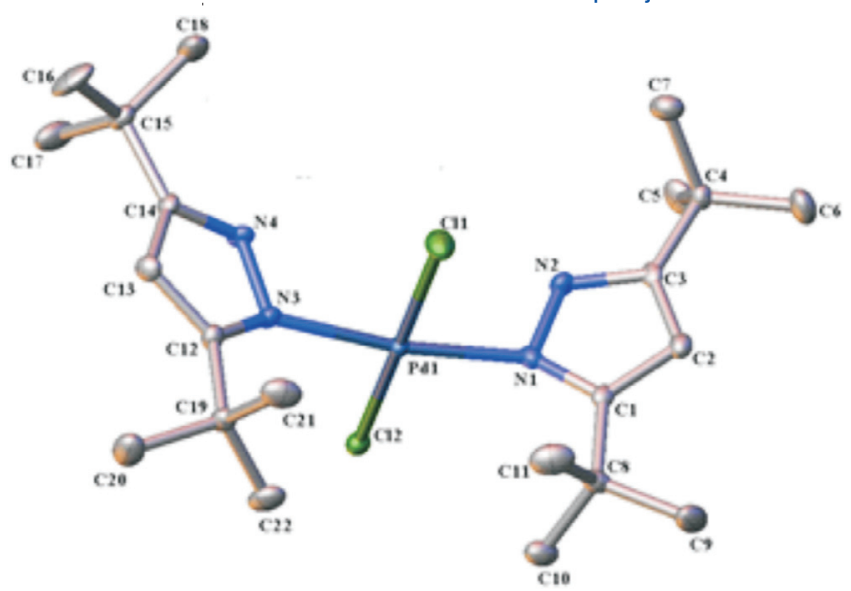

Figure 1 Molecular structure for complex 2. Hydrogen atoms, disordered ${ }^{t} B u$ group and solvent molecule omitted for clarity. Selected bond lengths $(\AA)$ : $\mathrm{Pd}(1)-\mathrm{N}(1), 2.012(2) ; \operatorname{Pd}(1)-\mathrm{N}(3), 2.018(2) ; \mathrm{Pd}(1)-\mathrm{Cl}(1)$ 2.2861(8); $\mathrm{Pd}(1)-\mathrm{Cl}(2), 2.3332(8)$. Selected bond angles ( $\left.{ }^{\circ}\right)$ : $\mathrm{Cl}(1)-\mathrm{Pd}(1)-$ $\mathrm{Cl}(2), 175.94(3) ; \mathrm{N}(1)-\mathrm{Pd}(1)-\mathrm{Cl}(1), 86.70(7) ; \mathrm{N}(1)-\mathrm{Pd}(1)-\mathrm{Cl}(2), 92.14(7)$ $\mathrm{N}(1)-\mathrm{Pd}-\mathrm{N}(3), 171.86(9) ; \mathrm{N}(3)-\mathrm{Pd}(1)-\mathrm{Cl}(1), 87.22(7) ; \mathrm{N}(3)-\mathrm{Pd}(1)-\mathrm{Cl}(2)$ 93.56(7).

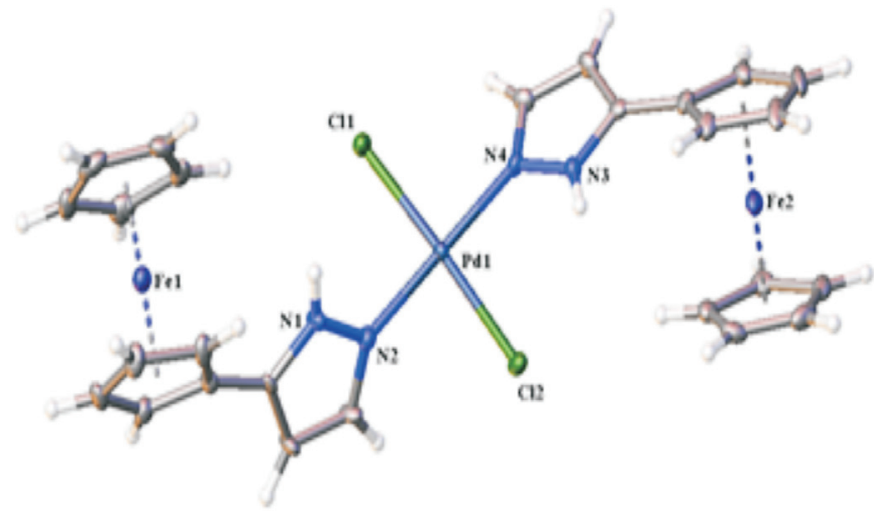

Figure 2 Molecular structure for complex 3 . Selected bond lengths $(\AA)$ : $\mathrm{Pd}(1)-\mathrm{N}(2), 1.999(4) ; \mathrm{Pd}(1)-\mathrm{N}(4), 2.007(4) ; \mathrm{Pd}(1)-\mathrm{Cl}(1), 2.3006(13)$; $\mathrm{Pd}(1)-\mathrm{Cl}(2), 2.2063(12)$. Selected bond angles $\left(^{\circ}\right)$ : $\mathrm{Cl}(1)-\mathrm{Pd}(1)-\mathrm{Cl}(2)$ 175.06(5); $\mathrm{N}(2)-\mathrm{Pd}(1)-\mathrm{N}(4), 179.72(18) ; \mathrm{N}(2)-\mathrm{Pd}(1)-\mathrm{Cl}(1), 89.41(12)$; $\mathrm{N}(2)-\mathrm{Pd}-\mathrm{Cl}(2), 89.10(12) ; \mathrm{N}(4)-\mathrm{Pd}(1)-\mathrm{Cl}(1), 90.81(12) ; \mathrm{N}(4)-\mathrm{Pd}(1)-\mathrm{Cl}(2)$, 90.70(12).

$\mathrm{N}(3)-\mathrm{Pd}(1)-\mathrm{Cl}(1), 87.22(7) ; \mathrm{N}(3)-\mathrm{Pd}(1)-\mathrm{Cl}(2), 93.56(7))$, whereas in $3 . \mathrm{CH}_{2} \mathrm{Cl}_{2}$ there is just a slight distortion from the square planar geometry to the following bond angles: $\mathrm{N}(2)-\mathrm{Pd}(1)-\mathrm{Cl}(1)$, 89.41(12); $\mathrm{N}(2)-\mathrm{Pd}-\mathrm{Cl}(2), 89.10(12) ; \mathrm{N}(4)-\mathrm{Pd}(1)-\mathrm{Cl}(1), 90.81(12)$; $\mathrm{N}(4)-\mathrm{Pd}(1)-\mathrm{Cl}(2), 90.70(12))$. Similar distortions in square planar geometries of $\mathbf{2} \cdot \mathrm{CH}_{2} \mathrm{Cl}_{2}$ and $\mathbf{2 . 1} / \mathbf{2} \mathrm{Et}_{2} \mathrm{O}$ have been observed by $\mathrm{Li}$ et al. ${ }^{24}$ The average $\mathrm{Pd}-\mathrm{N}$ bond lengths for $2 . \mathrm{CHCl}_{3}$ and $3 . \mathrm{CH}_{2} \mathbf{C l}_{2}$ are 2.105 (2) $\AA$ and 2.003 (4) $\AA$, respectively. These average Pd-N bond lengths are longer in $\mathbf{2} \cdot \mathrm{CHCl}_{3}$ than the average $\mathrm{Pd}-\mathrm{N}$ distance reported by $\mathrm{Li}$ et al. ${ }^{24}$ for $2 . \mathrm{CH}_{2} \mathrm{Cl}_{2}$ and $2.1 / 2 \mathrm{Et}_{2} \mathrm{O}$ (2.026(10) $\AA$ ), but the reported average Pd-N distance is significantly shorter in $3 . \mathrm{CH}_{2} \mathrm{Cl}_{2}$. The average $\mathrm{Pd}-\mathrm{Cl}$ bond lengths for 2. $\mathrm{CHCl}_{3}$ and $3 . \mathrm{CH}_{2} \mathrm{Cl}_{2}$ were found to be 2.3010 (8) $\AA$ and 2.303 (12) $\AA$, respectively.

On the other hand, the nickel atom's geometry in 4 is a disordered tetrahedron where bond angles vary between $98.76(14)^{\circ}$ and $126.81(4)^{\circ}$. A similar distortion was reported by Nelana et al. ${ }^{20}$ for the structure of $\left[(3,5-\mathrm{Mepz})_{2} \mathrm{NiBr}_{2}\right]$ where bond angles for the nickel complex vary between $98.90(11)^{\circ}$ and 125.94(4) ${ }^{\circ}$. Similarly, the average Ni-N bond lengths for 4 were 1.9695 (5) $\AA$ and 2.0669 (10) $\AA$. The average Ni-Br bond lengths for 4 were also 2.3697 (10) $\AA$ and 2.4620 (5) $\AA$. These data agrees with what was earlier reported..$^{19}$ Selected bonds lengths and angles of 2 and 3 are stated under each molecular structure.

\subsection{Catalytic Studies}

\subsubsection{Transfer Hydrogenation of Sorbic Acid}

The pyrazolyl palladium and nickel complexes (1-6) were evaluated as catalysts for the transfer hydrogenation of sorbic acid, with formic acid as the source of hydrogen. Many phosphino nickel(II) and palladium(II) complexes are well-known catalysts for the hydrogenation of olefinic double bonds, ${ }^{26-29}$ some of them featuring $\mathrm{P}^{\wedge} \mathrm{N}$ donor ligands..$^{29,30}$ These hydrogenation reactions were first carried out in the presence of a base, such as $\mathrm{KOH}$, which facilitates the deprotonation of the formic acid to formate ion. The formate ion then coordinates to the metal centre leading to decomposition of the formic acid with the aid of the intermediate, [M]-OOCH as an active catalyst, to produce $\mathrm{H}_{2}$ and $\mathrm{CO}_{2} \cdot{ }^{29}$ This accelerates $\mathrm{H}_{2}$ heterolysis and causes the catalytic process. ${ }^{20(b), 30}$

A typical hydrogenation reaction was performed with sorbic acid and a complex present in a $200: 1$ mole ratio at $90^{\circ} \mathrm{C}$ for $12 \mathrm{~h}$ (Fig. SI-3). It is worth noting that the hydrogenation process did not take place when the pre-catalyst was not added. Catalytic activities (in terms of conversions of sorbic acid) are very good with the palladium complexes and in the order $\mathbf{2}>\mathbf{3}>\mathbf{1}$; but poor for the nickel complexes, except for 4 , which gave $62 \%$ conversion (Table 2), having a turnover number (TON) of 124 and turnover frequency (TOF) of 10 . However, the selectivity towards the distribution of the products is quite significant for all the complexes. Considering the effect of substituents (methyl, tertiary-butyl, and ferrocenyl) on complexes 1-3, the order of catalytic activity is $2>\mathbf{3}>\mathbf{1}$ in terms of conversion of sorbic acids. Complex 2 gave $100 \%$ conversion of sorbic acid in $12 \mathrm{~h}$ compared to $67 \%$ and $74 \%$ for complexes 1 and 3, respectively. A similar trend is observed in their TON and TOF values. However, there is not much difference in their selectivities towards 2-hexenoic and 4-hexenoic acids (Table 2, Fig. SI-4). The excellent activity of complex 2 might be due to the solubility of this compound provided by the tertiary-butyl substituent on the pyrazolyl ligand.

The pyrazolyl nickel and palladium catalyzed hydrogenation of sorbic acid, in this study, proceeds via a two-step (sequential) reaction. The first step involves the formation of the intermediates, 4-hexenoic and 2-hexenoic acids, and further hydrogenation of the hexenoic acid isomers in the second step produces hexanoic acid (Scheme 2). ${ }^{31}$

In an attempt to find out if the $\mathrm{C}=\mathrm{C}$ bonds of the intermediates 4-hexenoic and 2-hexenoic acids would be fully saturated, the hydrogenation reaction was run for $24 \mathrm{~h}$ using complex 2 . Interestingly, the product distribution after $24 \mathrm{~h}$ was only slightly different from when the reaction was run for $12 \mathrm{~h}$, namely $82 \%$ hexanoic acid, $13 \%$ 2-hexenoic acid and $5 \%$ 4-hexenoic acids for $24 \mathrm{~h}$ vs $79 \%$ hexanoic acid, $14 \%$ 2-hexenoic acid and $7 \%$ 4-hexenoic acids for $12 \mathrm{~h}$ (Table 2, entries 2 and 3 ).

\subsection{2.. Hydrogenation of Sorbic Acid with Molecular Hydrogen}

We also carried out the hydrogenation of sorbic acid with molecular hydrogen and complexes 1-6. In a typical experiment, $5 \mathrm{mmol}$ of sorbic acid and $2.5 \mu \mathrm{mol}(0.05 \mathrm{~mol} \%)$ of the precatalysts were added to a reactor and ran for periods ranging from $0.5 \mathrm{~h}$ to $2 \mathrm{~h}$, at $5 \mathrm{bar}$ and $40{ }^{\circ} \mathrm{C}$. The complex to sorbic acid ratio was 1:200, and the reaction was with palladium catalysts monitored by ${ }^{1} \mathrm{H} N \mathrm{NR}$ spectroscopy. All six complexes produced active catalysts, leading to the same products observed with 
Table 2 Transfer hydrogenation of sorbic acid. ${ }^{\text {a }}$

\begin{tabular}{|c|c|c|c|c|c|c|c|}
\hline \multirow[t]{2}{*}{ Entry } & \multirow[t]{2}{*}{ Complex } & \multirow[t]{2}{*}{ Conversion } & \multirow[t]{2}{*}{ TON } & \multirow[t]{2}{*}{ TOF } & \multicolumn{3}{|c|}{ Amount of products detected $/ \%^{\mathrm{b}}$} \\
\hline & & & & & Hexanoic acid & 2-Hexenoic acid & 4-Hexenoic acid \\
\hline 1 & 1 & 67 & 134 & 11 & 76 & 15 & 9 \\
\hline 2 & 2 & 100 & 200 & 17 & 79 & 14 & 7 \\
\hline 3 & $2^{c}$ & 100 & 200 & 8 & 82 & 13 & 5 \\
\hline 4 & 3 & 74 & 148 & 12 & 78 & 13 & 9 \\
\hline 5 & 4 & 62 & 124 & 10 & 72 & 20 & 8 \\
\hline 6 & 5 & 22 & 44 & 4 & 70 & 23 & 7 \\
\hline 7 & 6 & 10 & 20 & 2 & 61 & 30 & 9 \\
\hline
\end{tabular}

${ }^{\text {a }}$ Reaction conditions: $2.5 \mu \mathrm{mol}(0.5 \mathrm{~mol} \%)$ of the complex; $0.5 \mathrm{mmol}$ of sorbic acid; $5 \mathrm{~mL}$ of methanol; $20 \mathrm{mmol} \mathrm{formic} \mathrm{acid;} 4 \mathrm{mmol} \mathrm{KOH} ; 90{ }^{\circ} \mathrm{C} ; 12 \mathrm{~h}$.

${ }^{\mathrm{b}}$ Conversions were estimated by ${ }^{1} \mathrm{H}$ NMR spectroscopy using dioxane as an internal standard. Each run was performed in duplicate. TOF in mol substrate mol $_{\text {catalyst }}^{-1} \mathrm{~h}^{-1}$. ${ }^{\mathrm{c}}$ After 24 h. $10 \mu \mathrm{L}$ dioxane.

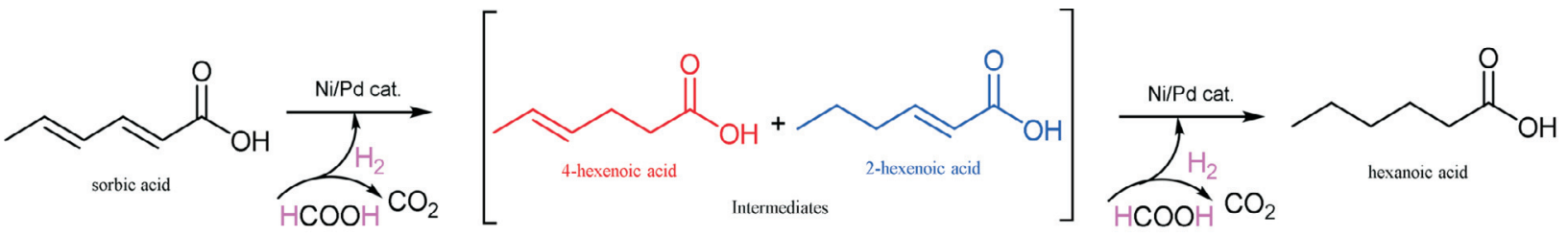

Scheme 2

Transfer hydrogenation of sorbic acid catalyzed by pyrazolyl nickel and palladium complexes, showing the intermediates to the final product.

formic acid (Scheme 2); the product distribution from the molecular hydrogenation reactions depicted in Table 3 is not so different from that of the formic acid reactions shown in Table 2 and Fig. 3.

As expected, the palladium complexes (1-3) are the most active, having the highest TOF of 400, all with complete conversion of sorbic acid within $0.5 \mathrm{~h}$. Only two of the nickel complexes ( 4 and 5) had a complete conversion, and only after $2 \mathrm{~h}$ (Table 3 , entries 7 and 11). Reactions, where the catalyst was a palladium complex, could be followed by ${ }^{1} \mathrm{H}$ NMR spectroscopy (Fig. 4). Furthermore, all the nickel and palladium catalysts did not completely hydrogenate the sorbic acid to hexanoic acid within $0.5 \mathrm{~h}$, and selectivities for 2-hexenoic and 4-hexenoic acids were as high as $37 \%$ and $30 \%$, respectively (Table 3). These results indicate the conditions under which any of these intermediate products can optimally be obtained if partial hydrogenation compounds are the targeted products. This product distribution is depicted in Table 3 and in Fig. 4, which shows the ${ }^{1} \mathrm{H}$ NMR spectral time study with complex 2 .

At $0.5 \mathrm{~h}, 20 \%$ conversion of sorbic acid was observed with complex 4 (Fig. 4). This conversion resulted in $37 \%$ and $9 \%$ selectivity towards 2-hexenoic acid and 4-hexenoic acid, respectively (Table 3, entry 4). After $1.5 \mathrm{~h}$, the conversion was greatly increased to $99 \%$ with $21 \%$ selectivity towards 2-hexenoic acid, and $2 \%$ of 4 -hexenoic was detected (Table 3, entry 6). Further increment in the reaction time (after $2 \mathrm{~h}$ ) only formed hexanoic acid with $100 \%$ conversion of sorbic acid (Table 3, entry 7). Similar observations were also seen using complexes 5 and $\mathbf{6}$ with $22 \%$ and $18 \%$ conversions, respectively, at $0.5 \mathrm{~h} .{ }^{32}$ Results for the catalytic tests are summarized in Table 3. Our results clearly

Table 3 Molecular hydrogenation of sorbic acid. ${ }^{a}$

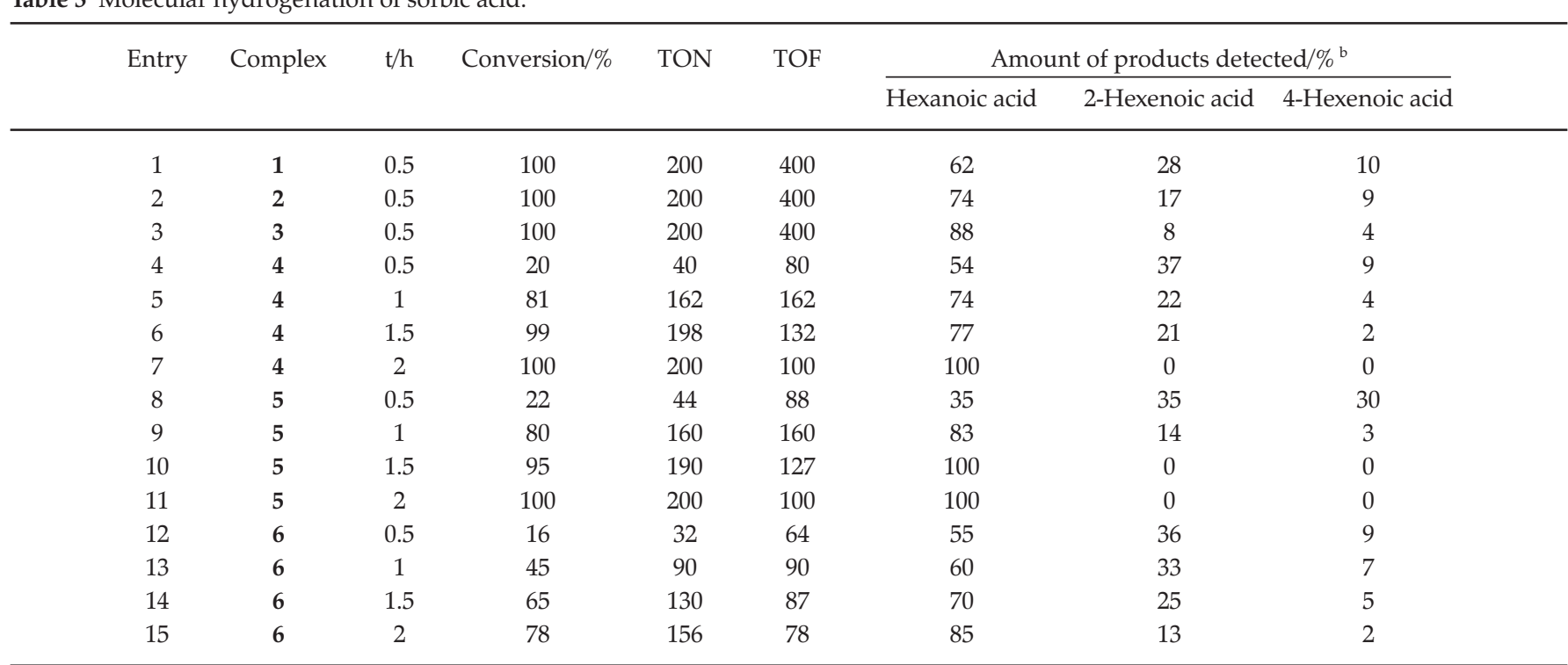

${ }^{\text {a }}$ Reaction conditions: $2.5 \mu \mathrm{mol}(0.5 \mathrm{~mol} \%)$ of the catalyst precursor; $0.5 \mathrm{mmol}$ of sorbic acid; $5 \mathrm{~mL}$ of methanol; $40{ }^{\circ} \mathrm{C} ; 5$ bar. $10 \mu \mathrm{L}$ dioxane.

${ }^{\mathrm{b}}$ Conversions were estimated by ${ }^{1} \mathrm{H}$ NMR spectroscopy using dioxane as an internal standard. Each run was performed in duplicate. TOF in mol substrate $_{\text {mol }}{ }_{\text {catalyst }}^{-1} \mathrm{~h}^{-1}$. 


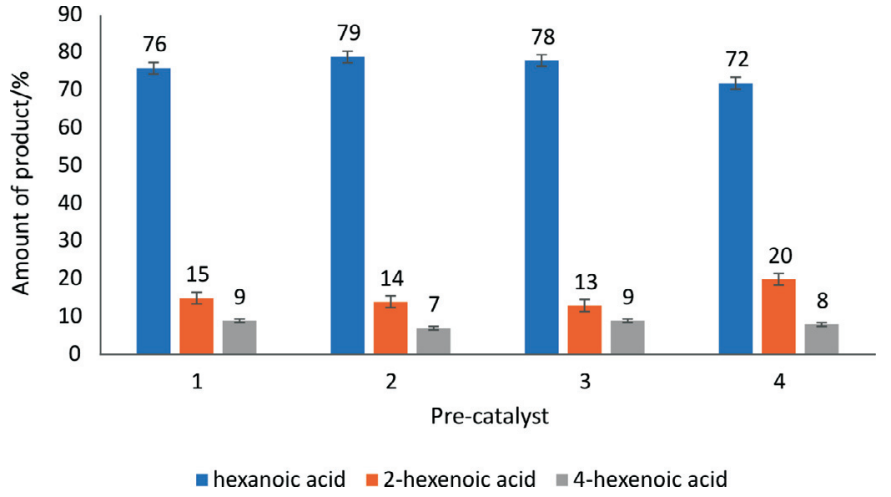

Figure 3 Hydrogenation of sorbic acid to 2-hexenoic, 4-hexenoic and hexanoic acids using formic acid with $62 \%$ and higher conversion. $2.5 \mu \mathrm{mol}(0.5 \mathrm{~mol} \%)$ of complex; $0.5 \mathrm{mmol}$ of sorbic acid; $5 \mathrm{~mL}$ of methanol; $20 \mathrm{mmol}$ formic acid; $4 \mathrm{mmol} \mathrm{KOH} ; 90^{\circ} \mathrm{C} ; 12 \mathrm{~h}$. $10 \mu \mathrm{L}$ dioxane. Conversions were estimated by ${ }^{1} \mathrm{H}$ NMR spectroscopy, using dioxane as an internal standard.

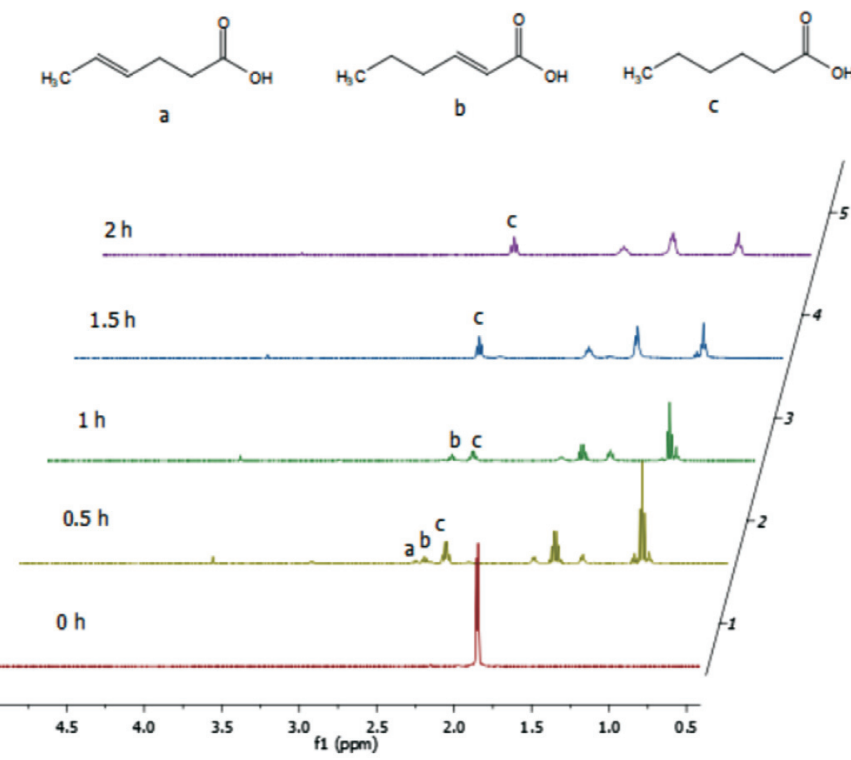

Figure $4{ }^{1} \mathrm{H}$ NMR spectra of hydrogenation of sorbic acid using complex 2 show the product distribution of the intermediates with $100 \%$ conversions at $0.5 \mathrm{~h}$ time intervals. $2.5 \mu \mathrm{mol}(0.5 \mathrm{~mol} \%)$ of the catalyst precursor; $0.5 \mathrm{mmol}$ of sorbic acid; $5 \mathrm{~mL}$ of methanol; $40^{\circ} \mathrm{C}$; 5 bar.

show that the less hindered $\mathrm{C}=\mathrm{C}$ bond in 4 -hexenoic acid is preferentially reduced over the more hindered one in 2-hexenoic acid. A detailed time-dependence study employing ${ }^{1} \mathrm{H}$ NMR spectroscopic technique was carried out on a sample of complex 2 with $100 \%$ conversion of sorbic acid (Fig. 4). The hydrogenation reaction's progress, with complex 2 , produced a betterresolved spectrum in the chemical shifts compared to its nickel analogue (complex 5), which produced a broad spectrum due to its paramagnetic property. The hydrogenation reaction proceeded with the formation of the intermediates (2-hexenoic and 4-hexenoic acid) (Fig. SI-6) and hexanoic acid after $0.5 \mathrm{~h}$. It is noted that by this time $(0.5 \mathrm{~h})$, the sorbic acid had been completely converted in all cases, and no traces of the substrate detected. Further increment in the time consumed one of the intermediates (4-hexenoic acid), followed by 2-hexenoic acid until all the $\mathrm{C}=\mathrm{C}$ bonds were fully saturated after $2 \mathrm{~h}$ with $100 \%$ selectivity towards hexanoic acid (Fig. 5).

\section{Conclusions}

Our study has shown how the nature of metal centres in pre-catalysts can affect hydrogenation reactions. This influence

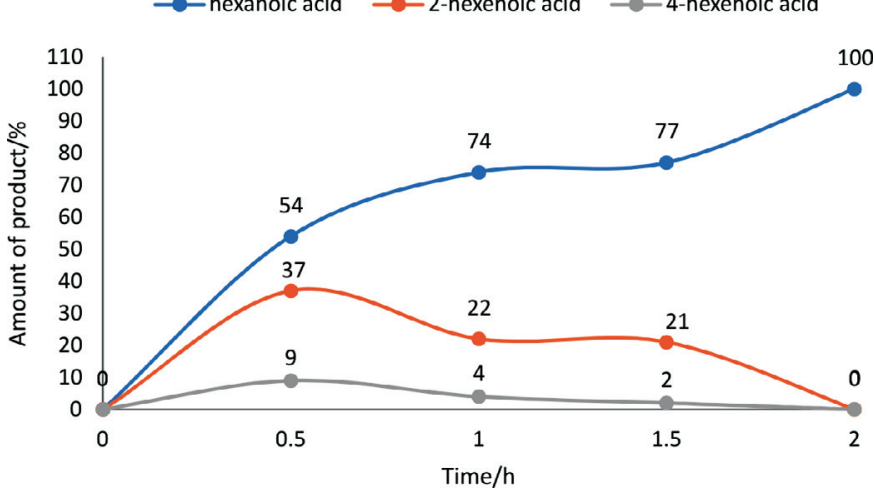

Figure 5 Hydrogenation of sorbic to 4-hexenoic, 2-hexenoic and hexanoic acids using molecular hydrogen with complex 4. $2.5 \mu \mathrm{mol}$ $(0.5 \mathrm{~mol} \%)$ of pre-catalyst; $0.5 \mathrm{mmol}$ of sorbic acid; $5 \mathrm{~mL}$ of methanol; $40^{\circ} \mathrm{C} ; 5$ bar.

is demonstrated by the higher efficiency of (pyrazolyl)palladium(II) complexes as compared to their corresponding nickel(II) counterparts. The activities of the catalysts with the same ligand are: $1>4,2>5$ and $3>6$. Furthermore, all the complexes investigated as sorbic acid hydrogenation catalysts, 1-6, gave appreciable conversions for catalytic hydrogenation of sorbic acid (i.e. greater than $52 \%$ ) compared with what was reported in the literature using ruthenium ${ }^{32,33}$ and rhodium..$^{33}$ The product distributions for the hydrogenation of sorbic acid using pre-catalysts (1-4), with ones with significant conversions, is shown in Fig. 3.

\section{Acknowledgements}

The authors are grateful to the Royal Society-Department for International Development, United Kingdom (RS-DFID-UK) (Registered Charity Number 207043) for funding. We also thank Dr Banele Vatsha and Dr Gershon Amenuvor for assisting in solving the crystal structures, data collections and X-ray analysis.

\section{Supplementary Material}

Supplementary information is provided in the online supplement, and additional data can be obtained free of charge from The Cambridge Crystallographic Data Centre at the addresses below. CCDC numbers 1878431 and 1878429 contain the supplementary crystallographic data for complexes 2 and 3, respectively. Contact details are: Director, CCDC, 12 Union Road, Cambridge, CB2 1EZ, UK (deposit@ccdc.cam.ac.uk or https:// www.ccdc.cam.ac.uk/structures/

\section{${ }^{8}$ ORCID iD}

O.E. Olaoye: (iD) orcid.org/0000-0002-7236-2823

\section{References}

1 (a) G. Hoge, Synthesis of both enantiomers of a p-chirogenic 1,2-bisphospholanoethane ligand via convergent routes and application to rhodium-catalysed asymmetric hydrogenation of CI-1008 (Pregabalin), J. Am. Chem. Soc., 2003, 125, 10219-10227; (b) K.B. Hassen, Y. Hsiaso, F. Xu, N. Ikemoto, Y. Sun, F. Spindler, C. Malan, E.J.J. Grabowski and J.D. Armstrong, Highly efficient asymmetric synthesis of sitagliptin, J. Am Chem. Soc., 2009, 131, 8798-8804; (c) H.U. Blaser, B. Pugin, F. Spindler and M. Thommen, From a chiral switch to a ligand portfolio for asymmetric catalysis, Acc. Chem. Res., 2007, 40, 1240-1250; (d) L.A. Saudan, Hydrogenation processes in the synthesis of perfumery ingredients, Acc. Chem. Res., 2007, 40, 1309-1319.

2 F.H. Jardin, (S.J. Lippard ed.), Chlorotris(triphenylphosphine)rhodium(I): its chemical and catalytic reaction, Prog. Inorg. Chem., 1981, $28,63-202$. 
3 J.A. Osborn, F.H. Jardine, J.F. Young and G. Wilkinson, The preparation and properties of tris(triphenylphosphine)halogenorhodium(I) and some reactions thereof including catalytic homogeneous hydrogenation of olefins and acetylenes and their derivatives, J. Chem. Soc., 1966 (A), 1711-1731.

4 R.A. Farra-tobaz, Z. Wei, H. Jiao, S. Hinze and J.G. De Vries, Selective base-free transfer hydrogenation of $\alpha, \beta$-unsaturated carbonyl compounds using $i \mathrm{PrOH}$ or EtOH as hydrogen source, Chem. Eur. J., 2018, 24, 2725-2734.

5 (a) S. Bauri, S.N.R. Donthireddy, P.M. Illam and A. Rit, Effect of ancillary ligand in cyclometalated $\mathrm{Ru}(\mathrm{II})-\mathrm{NHC}$-catalyzed transfer hydrogenation of unsaturated compounds, Inorg. Chem., 2018, 57, 14582-14593; (b) S. Naskar and M. Bhattacharjee, Regiospecific solvent-free transfer hydrogenation of $\alpha, \beta$-unsaturated carbonyl compounds catalysed by a cationic ruthenium(II) compound, Tetrahedron Lett., 2007, 48, 465-467.

6 (a) P. Wang, H. Liu, M. Liu, R. Li and J. Ma, Immobilized Pd complexes over HMMS as catalysts for Heck cross-coupling and selective hydrogenation reactions, New J. Chem., 2014, 38, 1138-1143; (b) G. Shang, W. Li and Z. Zhang, in Catalytic Asymmetric Synthesis, (I. Ojima ed.), vol. 1,3rd edn., John Wiley and Sons, New York, USA, 2010, pp. 343-436.

7 Y. Liu, I.D. Gridnev and W. Zhang, Mechanism of the asymmetric hydrogenation of exocyclic $\alpha, \beta$-unsaturated carbonyl compounds with an iridium/BiphPhox catalyst: NMR and DFT studies, Angew. Chem. Int. Ed., 2014, 53, 1901-1905.

8 F. Nerozzi, Heterogeneous catalytic hydrogenation, Plat. Met. Rev., 2012, 56, 236-261.

9 (a) E. Bouwman, Handbook of Homogeneous Hydrogenation, (J.G. De Vries and C.J. Elsevier eds.), Wiley-VCH Verlag $\mathrm{GmbH}$ and $\mathrm{Co}$ KGaA, Weinheim, 2007, p. 93; (b) Z.R. Dong, Y.Y. Li, S.L. Yu, G.S. Sun and J.X. Gao, Asymmetric transfer hydrogenation of ketones catalysed by nickel complex with new PNO-type ligand, Chin. Chem. Lett., 2012, 23, 533-536; (c) Y.Y. Li, S.L. Yu, W.Y. Shen and J.X. Gao, Iron-, cobalt-, and nickel-catalysed asymmetric transfer hydrogenation of ketones, Acc. Chem. Res., 2015, 48, 2587-2598.

10 R.J. Liua, P.A. Croziera, C.M. Smith, D.A. Huculc, J. Blacksond and G. Salaita, Metal sintering mechanisms and regeneration of palladium/alumina hydrogenation catalysts, Appl. Catal A Gen., 2005, 282, 111-121.

11 (a) M. Shevlin, M.R. Friedfeld, H. Sheng, N.A. Pierson, J.M. Hoyl, L.C. Campeau and P.J. Chirik, Nickel-catalyzed asymmetric alkene hydrogenation of $\alpha \beta$-unsaturated esters: high-throughput experimentation-enabled reaction discovery, optimisation, and mechanism elucidation, J. Am. Chem. Soc., 2016, 138, 3562-3569; (b) A. Corma, S. Iborra and A. Velty. Chemical routes for the transformation of biomass into chemicals, Chem. Rev., 2007, 107, 2411-2502.

12 (a) E. Negishi, Handbook of Organopalladium Chemistry for Organic Synthesis, Wiley and Sons, New York, 2002,1, 229-247; (b) F.A. Harraz, S.E El-Hout, H.M. Killa and I.A. Ibrahim, Palladium nanoparticle stabilised by polyethylene glycol: efficient, recyclable catalyst for the hydrogenation of styrene and nitrobenzene, J. Catal., 2012, 286, 184-192.

13 B. Ding, Z. Zhang, Y. Liu, M. Sugiya, T. Imamoto and W. Zhang, Chemoselective transfer hydrogenation of $\alpha, \beta$-unsaturated ketones catalysed by pincer-Pd complexes using alcohol as a hydrogen source, Org. Lett., 2013, 15, 3690-3693.

14 A. Bacchi, M. Carcelli, M. Costa, A. Leporati, E. Leporati, P. Pelagatti, C. Pelizzi and G. Pelizzi, Palladium(II) complexes containing a P,N chelating ligand part II. Synthesis and characterisation of complexes with different hydrazinic ligands. Catalytic activity in the hydrogenation of double and triple C-C bonds, J. Organomet. Chem., 1997, 535, 107-120.

15 P.W.N.M. Leeuwen and C.J. Chadwick, Homogeneous Catalysts: Activity-Stability-Deactivation, Wiley-VCH Verlag, Germany, 2011.

16 M.W. Van Laren and C.J Elsevier, Selective homogeneous palla- dium(0)-catalysed hydrogenation of alkynes to (Z)-alkene. Angew . Chew. Int. Ed., 1999, 38, 3715-3717.

17 J. Elguero and E.J.R. Jacquier, Azoles VII, Assignment of the nuclear magnetic resonance signals of N-substituted pyrazole, Bull, Soc. Chim. Fran. 1968, 2, 707-711.

18 K. Niedenzu, J. Sorwatowski and S. Trofimenko, Boron derivatives of 3-ferrocenylpyrazole, Inorg. Chem., 1991, 30, 524-527.

19 (a) G.K. Anderson and M. Lin, Bis(benzonitrile)dichloro complexes of palladium and platinum, Inorg. Synth., 1990, 28, 60-63: (b) E. Ocansey, J. Darkwa and B.C.E. Makhubela, Bis(pyrazolyl)palladium(II) complexes as catalyst for Mizoroki-Heck cross-coupling reactions, Polyhedron, 2019, 166, 52-59.

20 (a) S.M. Nelana, J. Darkwa, I.A. Guzei and S.F. Mapolie, Ethylene polymerisation catalysed by substituted pyrazole nickel complexes, J. Organomet. Chem., 2004, 689, 1835-1842; (b) G. Amenuvor, B.C.E. Makhubela and J. Darkwa, Efficient solvent-free hydrogenation of levulinic acid to $\gamma$-valerolacetone by pyrazolylphosphite and pyrazolylphosphinite ruthenium(II) complexes, ACS Sustainable Chem. Eng., 2016, 4, 6010-6018.

21 APEX2, (including SAINT SADABS), Bruker AXS Inc., Madison, WI 2012.

22 G.M Sheldrick, SHELXT- Integrated space-group and crystal structure determination, Acta Crystallogr. Sect. Found. Adv., 2015, A71, 3-8.

23 G.M. Sheldrick, Crystal structure refinement with SHELXL, Acta Cryst., 2015, C71, 3-8.

24 K. Li, J. Darkwa, I.A. Guzei and S.F. Mapolie, Synthesis and evaluation of substituted pyrazoles palladium(II) complexes as ethylene polymerisation catalysts, J. Organomet. Chem., 2002, 660, 108-115.

25 C. Obuah, A. Munyaneza, I.A. Guzei and J. Darkwa, Ferrocenylpyrazolyl palladium complexes as catalysts for the polymerisation of 1-heptene and 1-octene to highly branched polyolefins, Dalton Trans., 2014, 43, 8940-8950.

26 (a) I.M. Augulo, E. Bouwman, R. Gorkum, S.M. Lok, M. Lutz and A.L. Spek, New nickel-containing homogenous hydrogenation catalysts structures of $\left[\mathrm{Ni}(\mathrm{o}-\mathrm{MeO}-\mathrm{dppol}) \mathrm{Cl}_{2}\right]$ and $\left[\mathrm{Ni}(\mathrm{dcpe}) \mathrm{Cl}_{2}\right]$, J. Mol. Cal., 2003, 202, 97-106; (b) Y. Liu, Z. Yi, X. Tan, X-Q. Dong and X. Zhang, Nickel-catalyzed asymmetric hydrogenation of cyclic sulfamide imines: efficient synthesis of chiral cyclic sulfamidates, iScience, 2019, $19,63-73$

27 A. Togni, C. Breutel, A. Schnyder, F. Spindler, H. Landert and A. Tijiani, A novel easily accessible chiral ferrocenyldiphosphine for highly enantioselective hydrogenation, allylic alkylation, and hydrogenation reactions, J. Am. Chem. Soc., 1994, 116, 4062-4066.

28 Y. Hamada, Y. Koseki, T. Fujii, T. Maeda, T. Hibino and K. Makino, Catalytic asymmetric hydrogenation of $\alpha$-amino- $\beta$-keto ester hydrochlorides using homogeneous chiral nickel nickel-bisphosphine complexes through DKR, Chem. Comm., 2008, 46, 6206-6208.

29 C. Pérez-Zúñigaa, C. Negrete-Vergarac, V. Guerchaisb, H. Le Bozecb, S.A. Moyaa and P. Aguirre, Hydrogenation of N-benzylideneaniline by palladium(II) catalysts with phosphorus-nitrogen ligands using formic acid as a renewable hydrogen source, Mol. Catal., 2019, 462, 126-131.

30 S.M. Lu, Z. Wang, J. Li, J. Xiao and C. Li, Base-free hydrogenation of $\mathrm{CO}_{2}$ to formic acid in water with an iridium complex bearing a $\mathrm{N}$, $\mathrm{N}^{\prime}$-diimine ligand, Green Chem., 2016, 18, 4553-4558.

31 J. Heinen, M.S. Tupayachi, B. Drießen-Hölscher, Biphasic homogeneous hydrogenation of sorbic acid with water-soluble ruthenium catalysts: aspects of mass transfer, Catalysis Today, 1999, 48, 273-278.

32 B. Drießen-Hölscher and J. Heinen, Selective two-phase hydrogenation of sorbic acid with novel water-soluble ruthenium complexes, J. Organomet. Chem., 1998, 570, 141-146.

33 A. Udvardy and Á. Kathó, Hydrogenation of sorbic acid in mono and biphasic systems catalysed by Rh(I)-phosphine complexes, React. Kinet. Catal. Lett., 2008, 95, 81-87. 


\section{Supplementary material to:}

O.E. Olaoye, O. Oyetunji, B.C.E. Makhubela, A. Muyaneza, G. Kumar and J. Darkwa, Catalytic Hydrogenation of Sorbic Acid using Pyrazolyl Palladium(II) and Nickel(II) Complexes as Precatalysts,

S. Afr. J. Chem., 2021, 74 (Special Edition), 50-56. 


\section{Catalytic Hydrogenation of Sorbic Acid using Pyrazolyl Palladium(II) and Nickel(II) Complexes as Precatalysts}

Oluwasegun E. Olaoye ${ }^{1}$, Olayinka Oyetunji ${ }^{1 *}$, Banothile C. E. Makhubela ${ }^{2}$, Apollinaire Muyaneza $^{1,4}$, Gopendra Kumar ${ }^{1}$ and James Darkwa ${ }^{2,3^{*}}$.

${ }^{1}$ Department of Chemistry, University of Botswana, Private Bag UB 00704, Gaborone, Botswana.

${ }^{2}$ Department of Chemical Sciences, University of Johannesburg, Kingsway Campus, Auckland Park, 2006, South Africa.

${ }^{3}$ Botswana Institute for Technology Research and Innovation, Machel Drive, Gaborone, Botswana.

${ }^{4}$ CREDERE Associates, LLC, 776 Main Street, Westbrook, ME 04092, USA.

*Corresponding Authors: oyetunji@ub.ac.bw; jdarkwa@,bitri.co.bw

$\underline{\text { Supplementary Information }}$
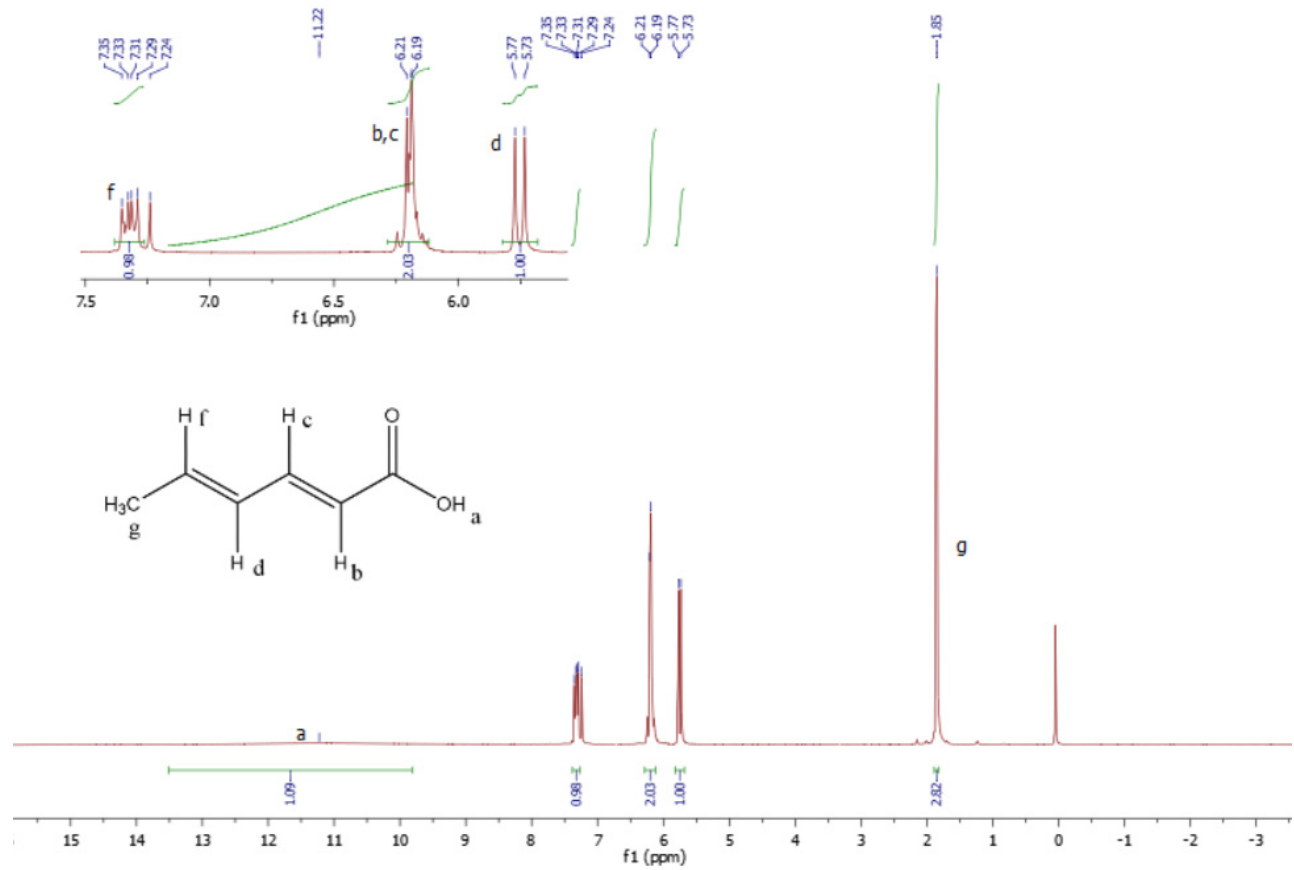

Figure SI-1. ${ }^{1} \mathrm{H}$ NMR spectrum of the substrate (sorbic acid) recorded in $\mathrm{CDCl}_{3}$. 


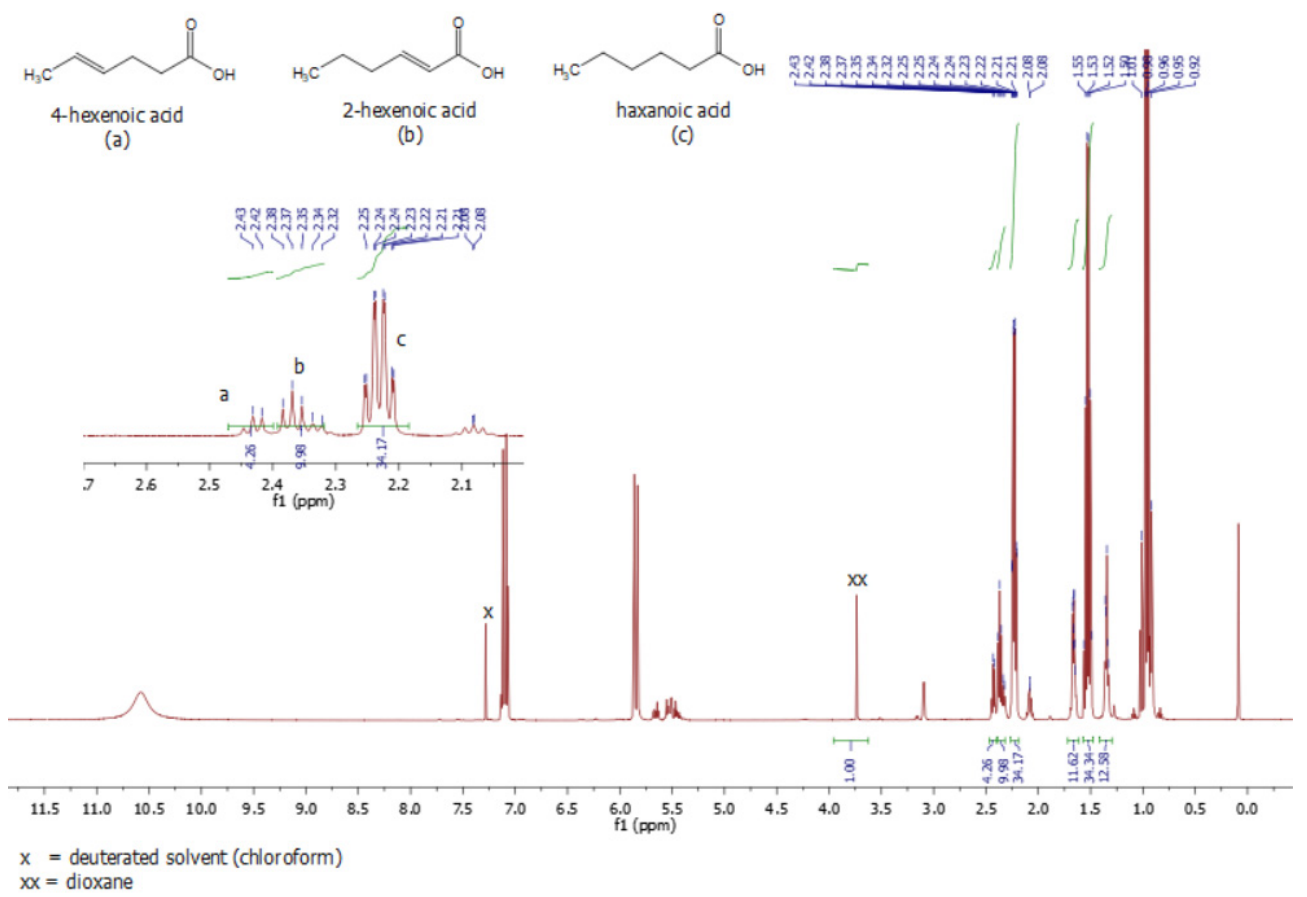

Figure SI-2. Representative ${ }^{1} \mathrm{H}$ NMR spectrum for the hydrogenation of sorbic acid involving the intermediate, using molecular hydrogen. $2.5 \mu \mathrm{mol}(0.5 \mathrm{~mol} \%)$ of catalysts; $0.5 \mathrm{mmol}$ of sorbic acid; $5 \mathrm{~mL}$ of methanol; $40{ }^{\circ} \mathrm{C}$; 5 bar. Using dioxane as an internal standard.

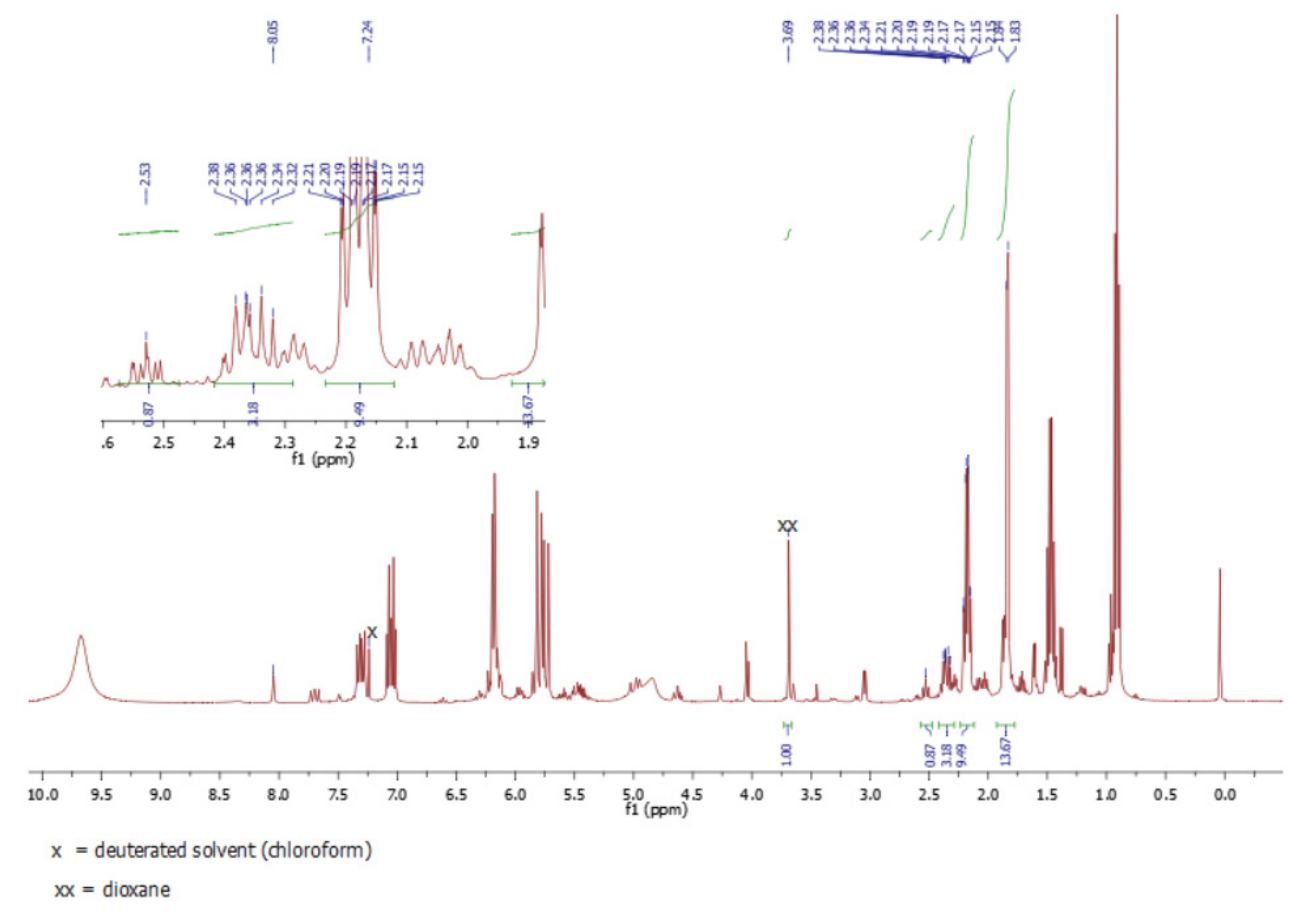

Figure SI-3. Representative ${ }^{1} \mathrm{H}$ NMR spectrum for the hydrogenation of sorbic acid involving the intermediate, using formic acid as the hydrogen source. $2.5 \mu \mathrm{mol}$ $(0.5 \mathrm{~mol} \%)$ of catalysts; $0.5 \mathrm{mmol}$ of sorbic acid; $5 \mathrm{~mL}$ of methanol; $90{ }^{\circ} \mathrm{C}$; $20 \mathrm{mmol}$ formic acid; $4 \mathrm{mmol} \mathrm{KOH}$. Using dioxane as an internal standard. 


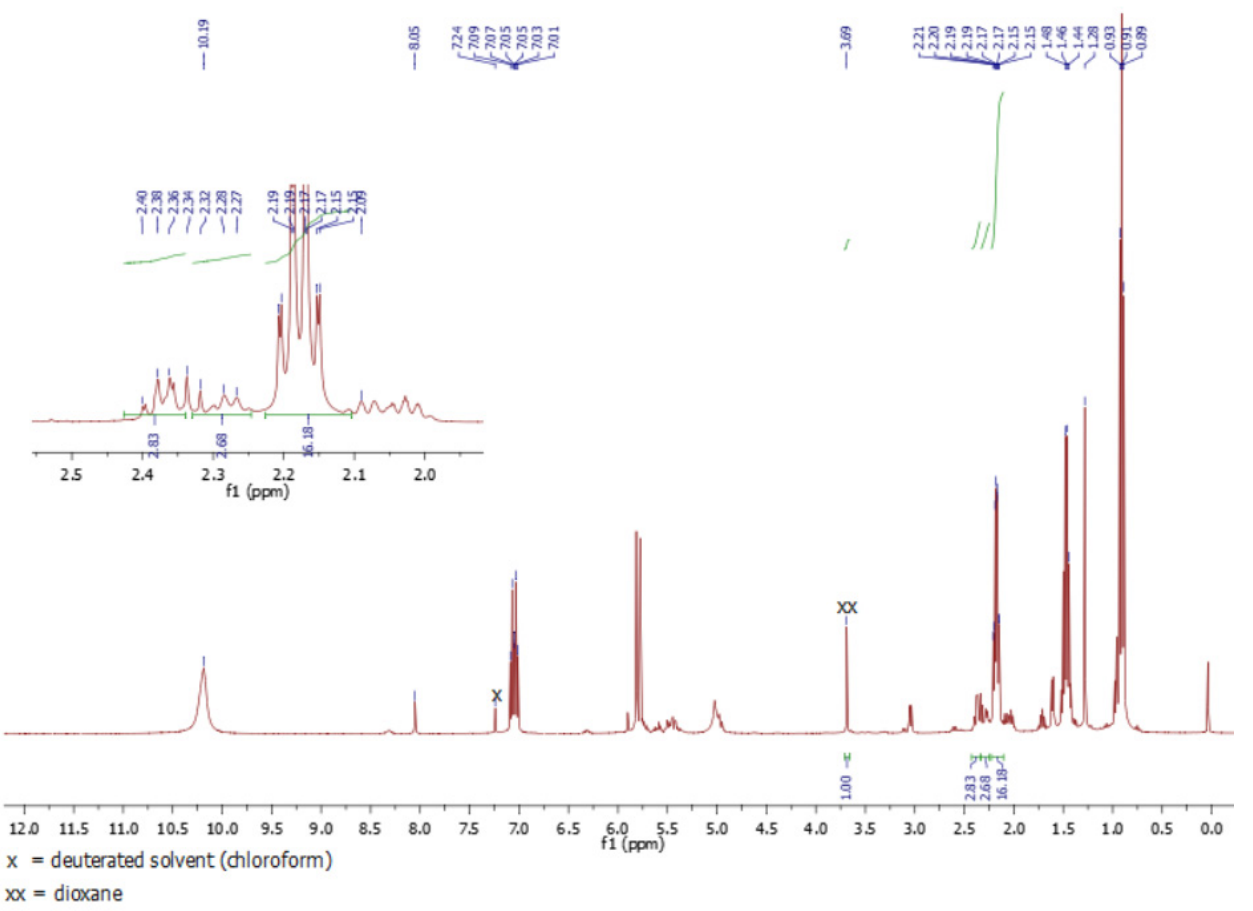

Figure SI-4. ${ }^{1} \mathrm{H}$ NMR spectrum for the hydrogenation of sorbic acid with catalyst 2 (at $100 \%$ conversion) using formic acid as the hydrogen source. $2.5 \mu \mathrm{mol}(0.5 \mathrm{~mol} \%)$ of precatalyst; $0.5 \mathrm{mmol}$ of sorbic acid; $5 \mathrm{~mL}$ of methanol; $90{ }^{\circ} \mathrm{C} ; 20 \mathrm{mmol}$ formic acid; $4 \mathrm{mmol} \mathrm{KOH}$. Using dioxane as an internal standard.
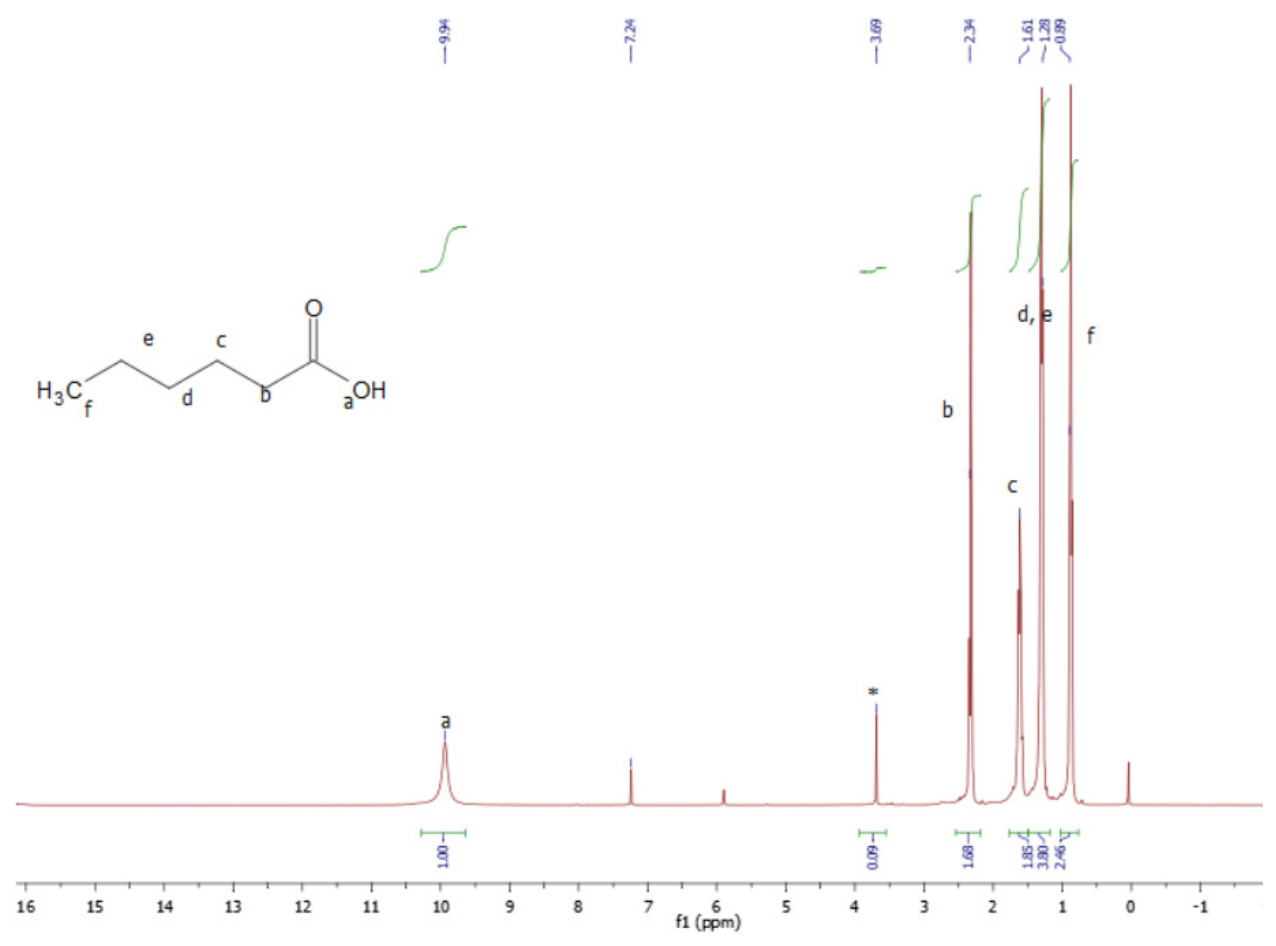

Figure SI-5. ${ }^{1} \mathrm{H}$ NMR spectrum for the hydrogenation of sorbic acid using complex 2 with $100 \%$ selectivity towards hexanoic acid. $2.5 \mu \mathrm{mol}(0.5 \mathrm{~mol} \%)$ of catalyst; $0.5 \mathrm{mmol}$ of sorbic acid; $5 \mathrm{~mL}$ of methanol; $40{ }^{\circ} \mathrm{C} ; 5 \mathrm{bar} ; 2 \mathrm{~h}$. Using dioxane as an internal standard. 


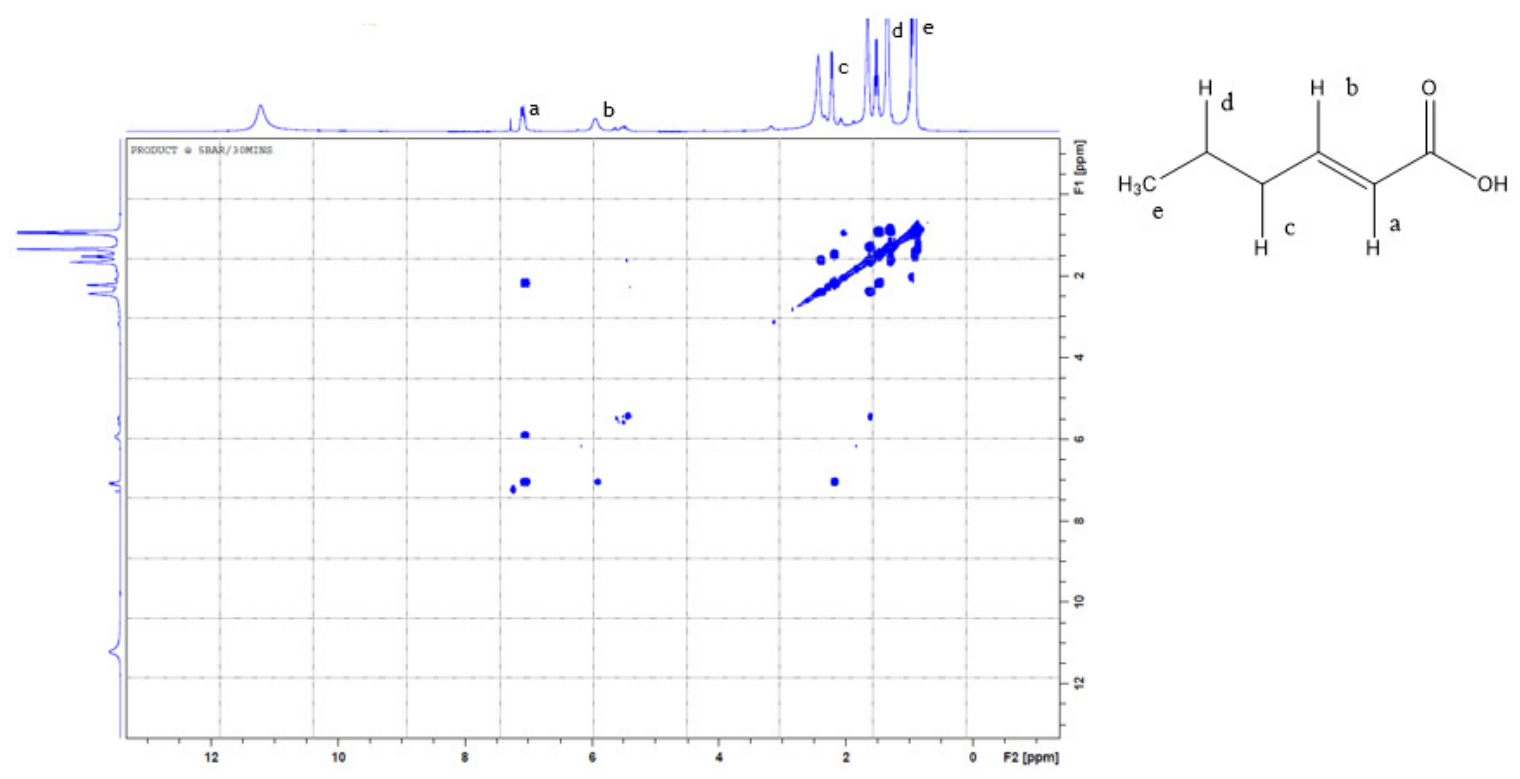

Figure SI-6. 2D NMR spectrum showing the production distributions of the intermediates for the hydrogenation of sorbic acid. $2.5 \mu \mathrm{mol}(0.5 \mathrm{~mol} \%)$ of catalyst; $0.5 \mathrm{mmol}$ of sorbic acid; $5 \mathrm{~mL}$ of methanol; $40{ }^{\circ} \mathrm{C}$; 5 bar.

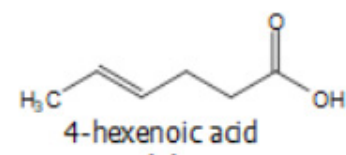

(a)

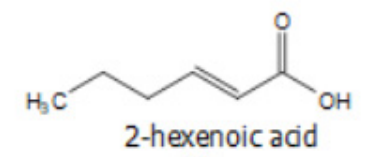

(b)

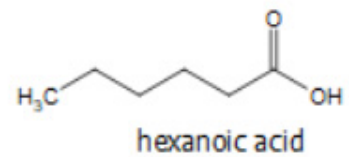

(c)

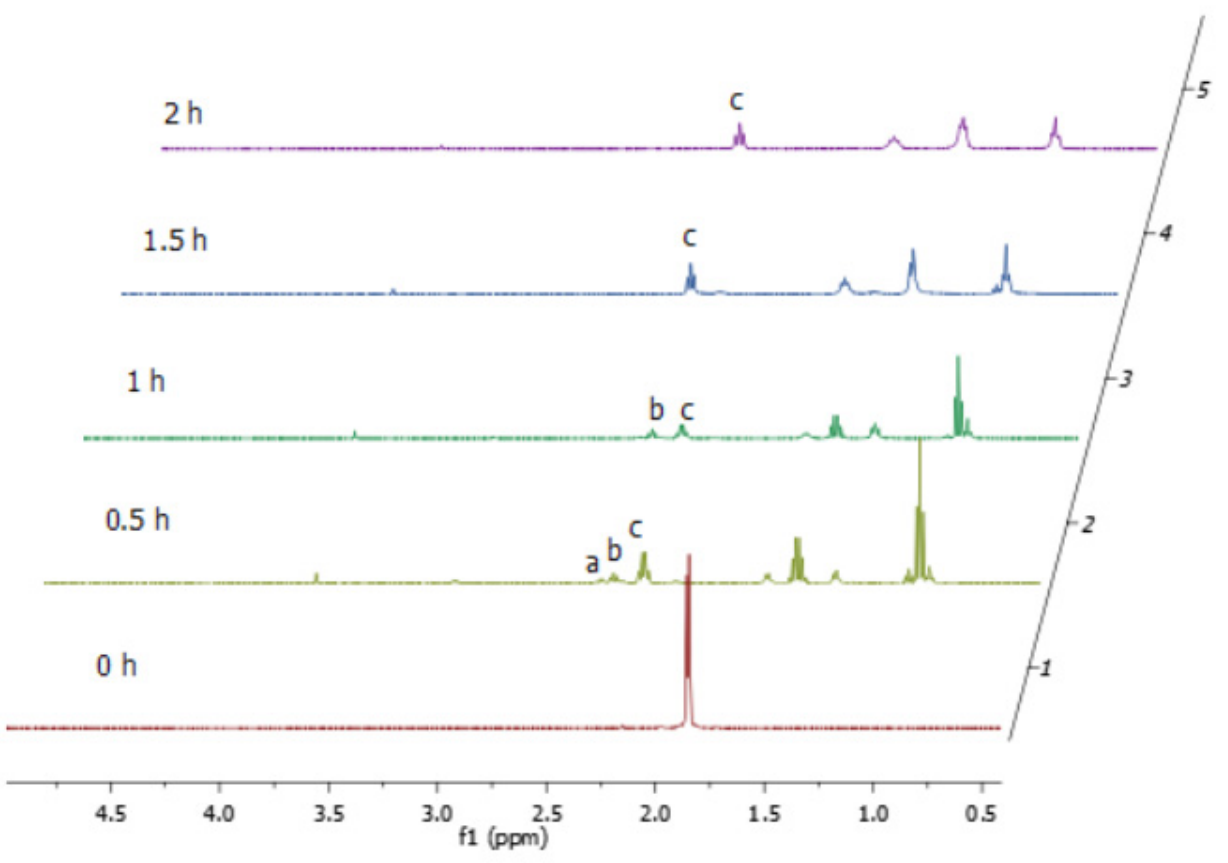

Figure SI-7a. Time-dependent studies on the hydrogenation of sorbic acid using catalysts. $2.5 \mu \mathrm{mol}(0.5 \mathrm{~mol} \%)$ of pre-catalyst; $0.5 \mathrm{mmol}$ of sorbic acid; $5 \mathrm{~mL}$ of methanol; $40^{\circ} \mathrm{C} ; 5$ bar. 


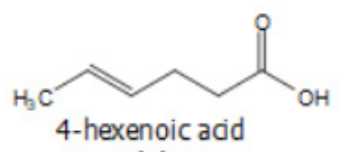

(a)

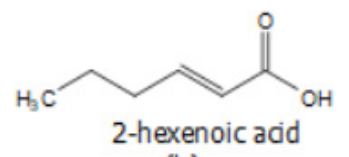

(b)

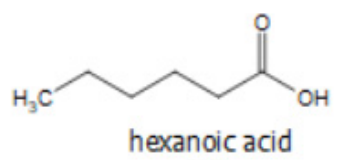

(c)

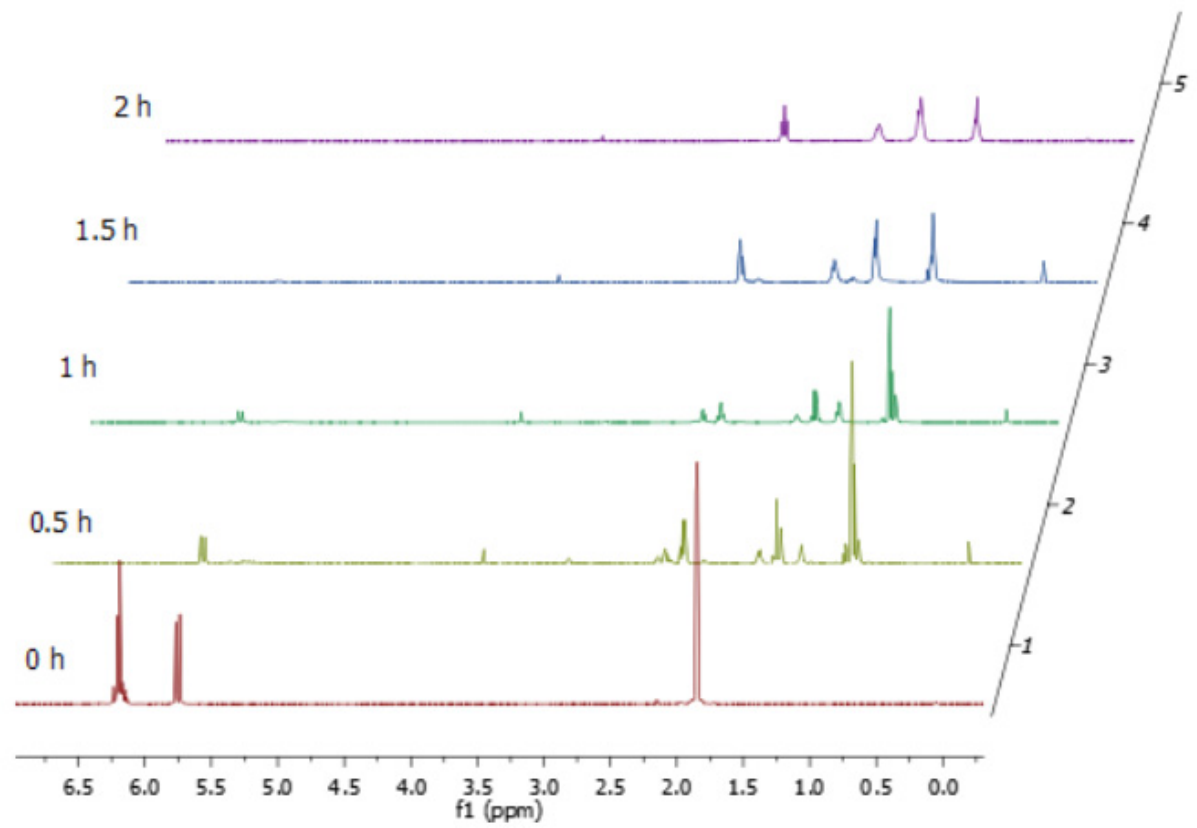

Figure SI-7b. Time-dependent studies on the hydrogenation of sorbic acid using catalysts (expanded region showing the full spectra).

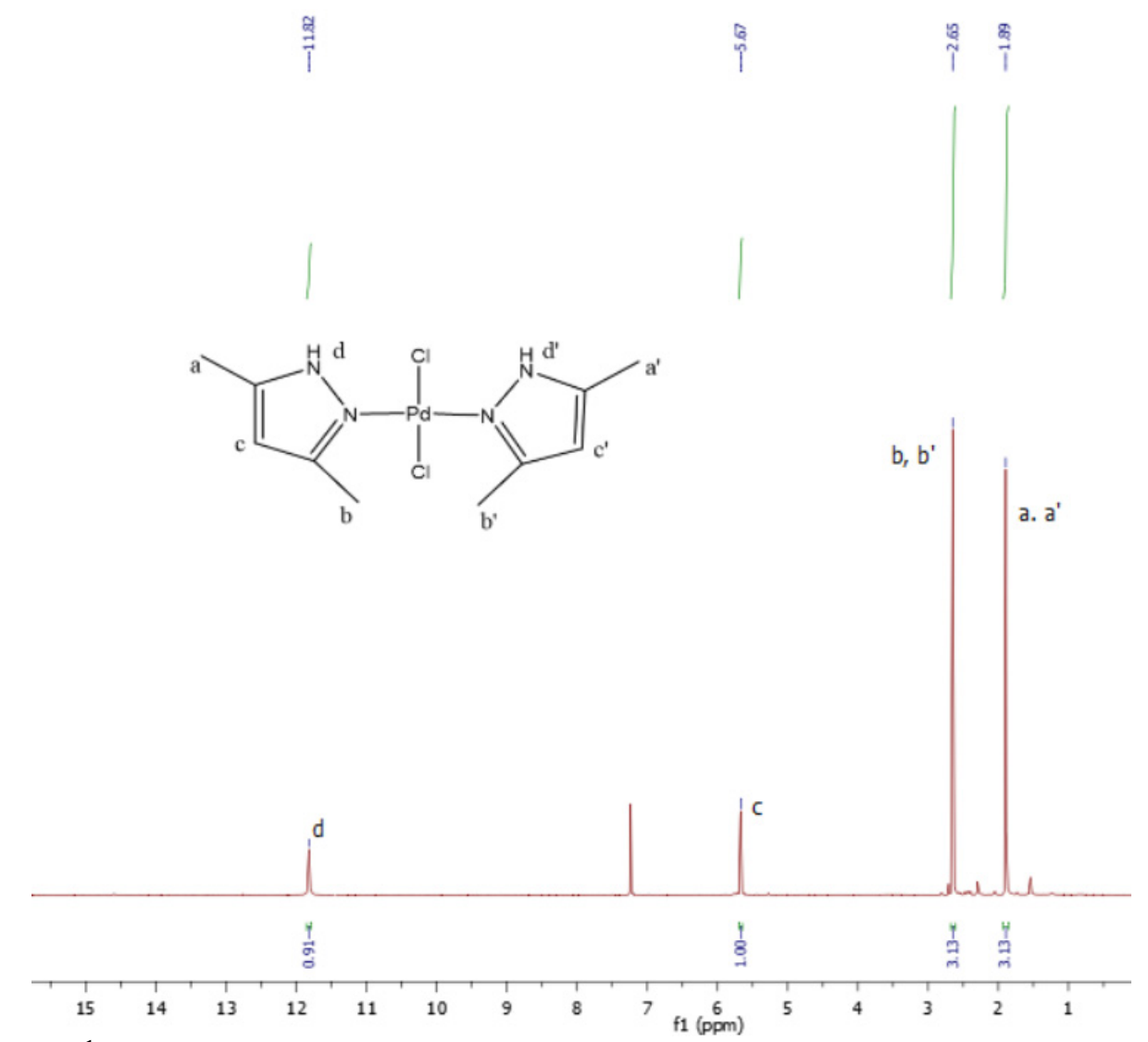

Figure SI-8. ${ }^{1} \mathrm{H}$ NMR spectrum of $\mathbf{1}$ recorded in $\mathrm{CDCl}_{3}$ 

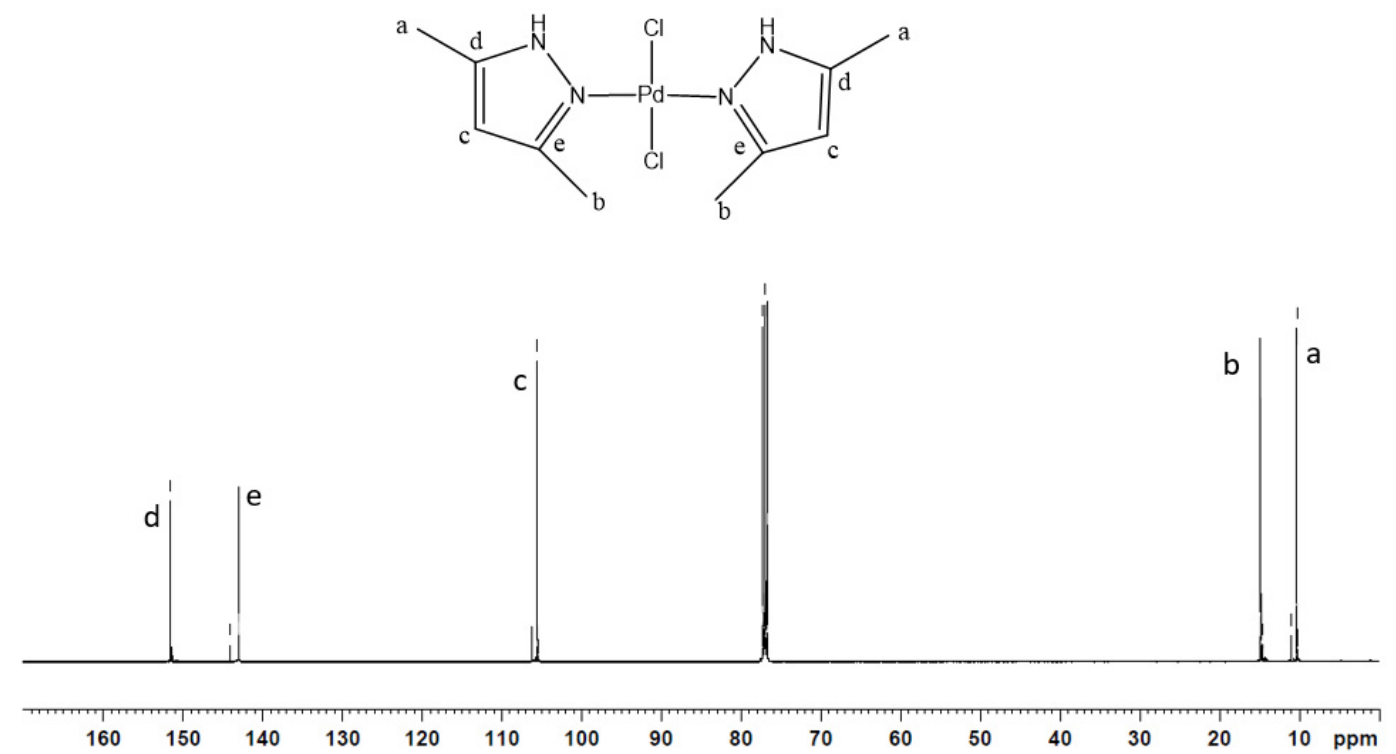

Figure SI-9. ${ }^{13} \mathrm{C}\left\{{ }^{1} \mathrm{H}\right\}$ NMR spectrum of $\mathbf{1}$ recorded in $\mathrm{CDCl}_{3}$

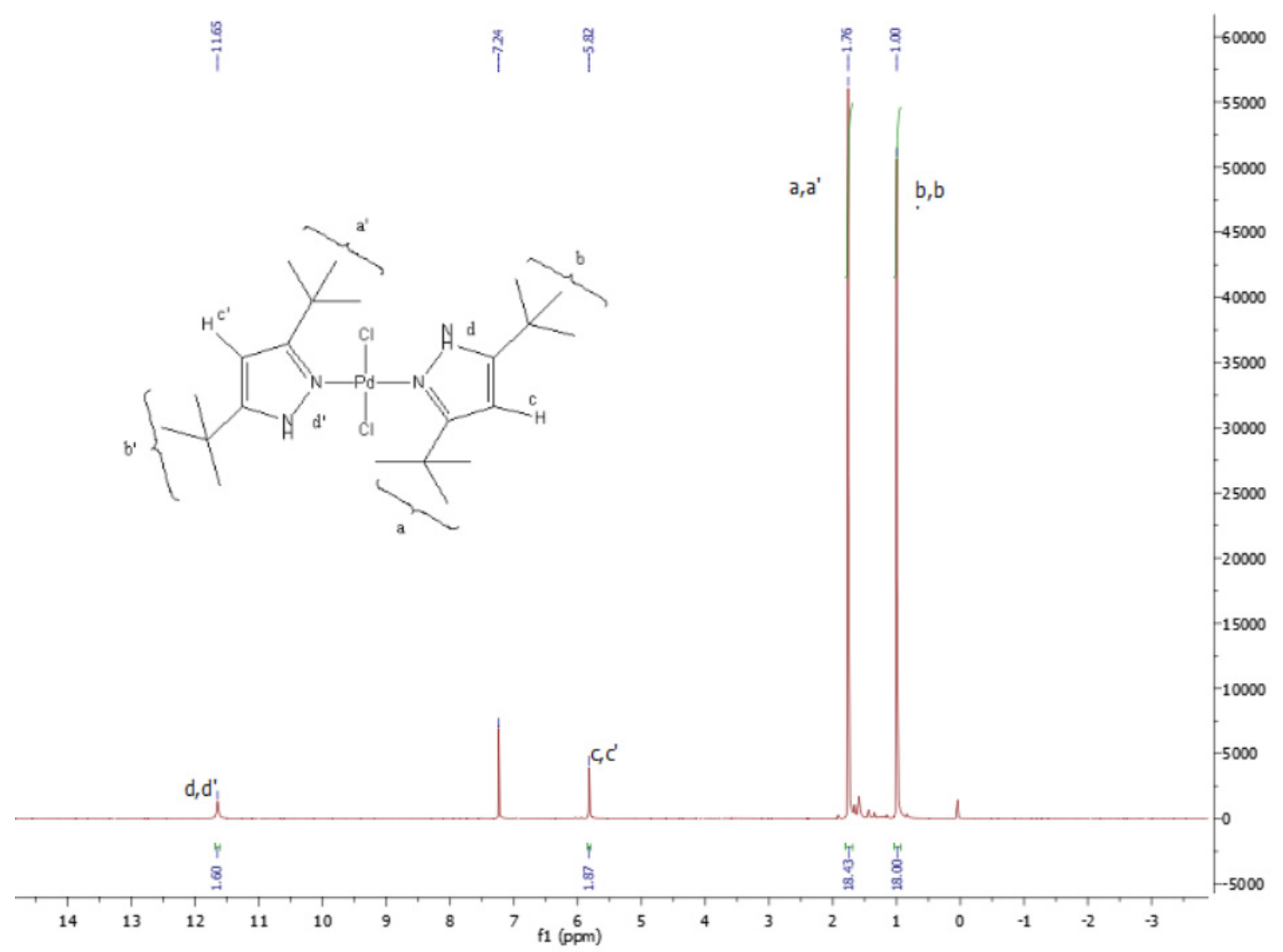

Figure S1-10. ${ }^{1} \mathrm{H}$ NMR spectrum of $\mathbf{2}$ recorded in $\mathrm{CDCl}_{3}$ 


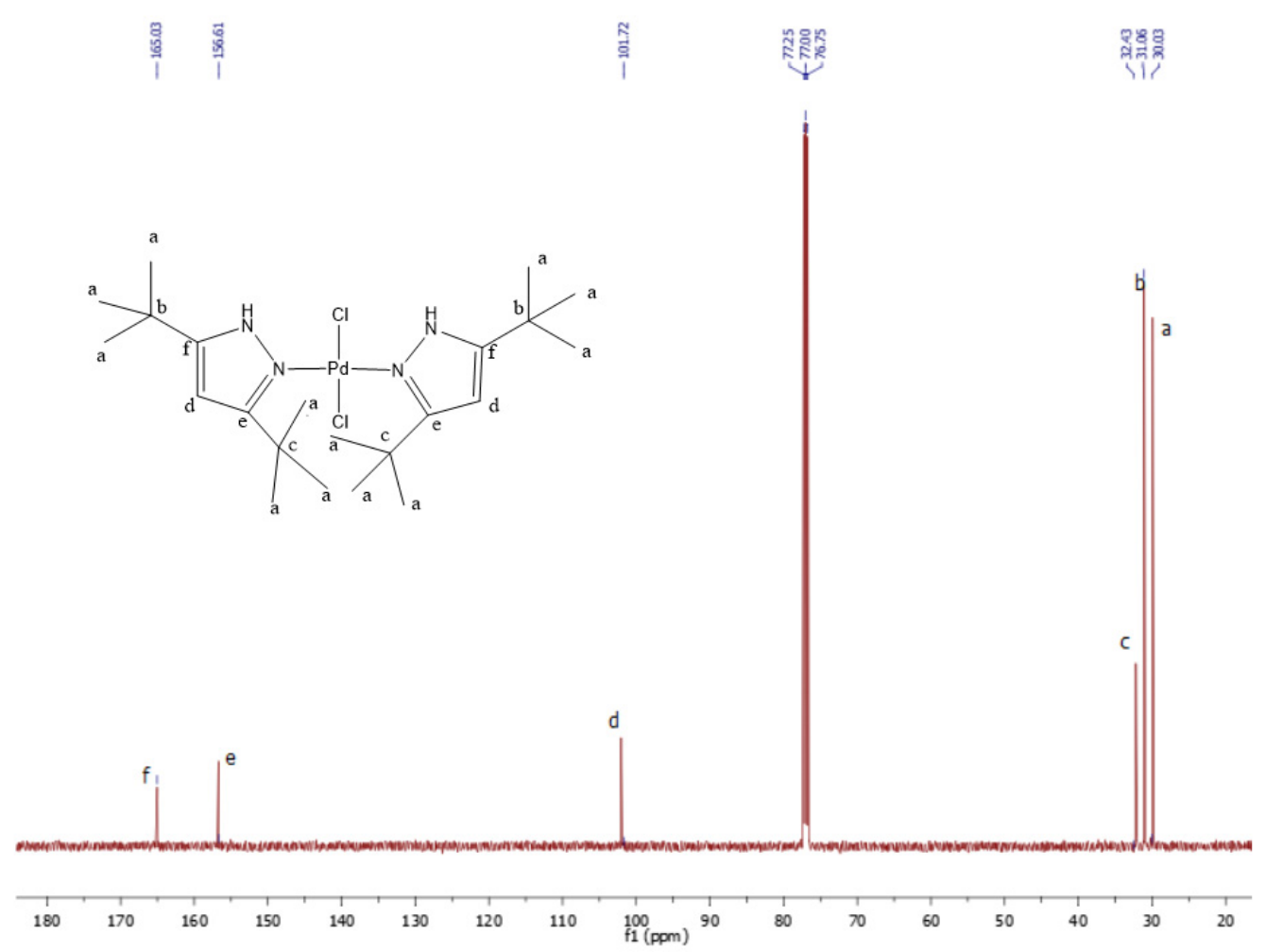

Figure S1-11. ${ }^{13} \mathrm{C}\left\{{ }^{1} \mathrm{H}\right\}$ NMR spectrum of 2 recorded in $\mathrm{CDCl}_{3}$

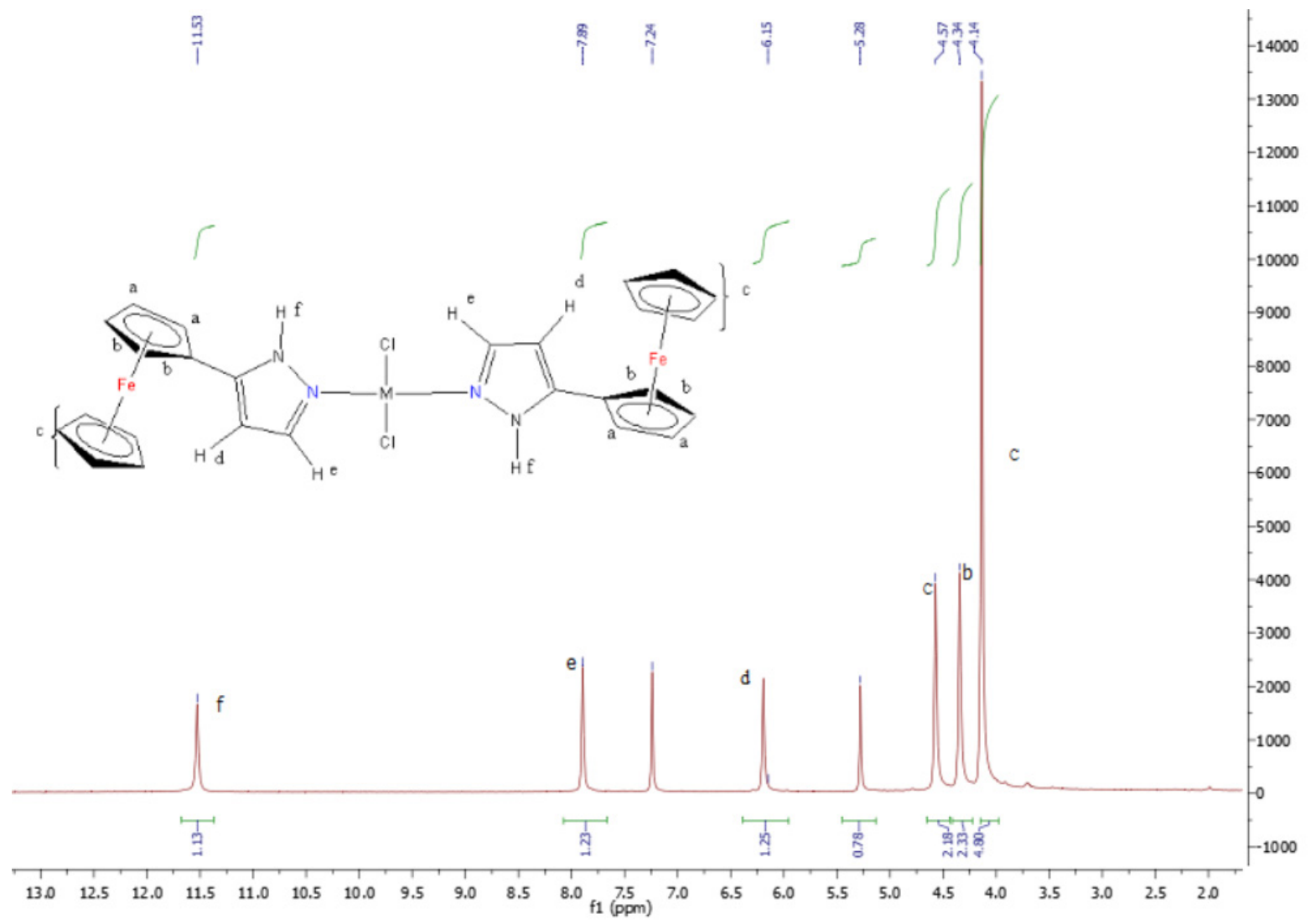

Figure S1-12. ${ }^{1} \mathrm{H}$ NMR spectrum of 3 recorded in $\mathrm{CDCl}_{3}$ 


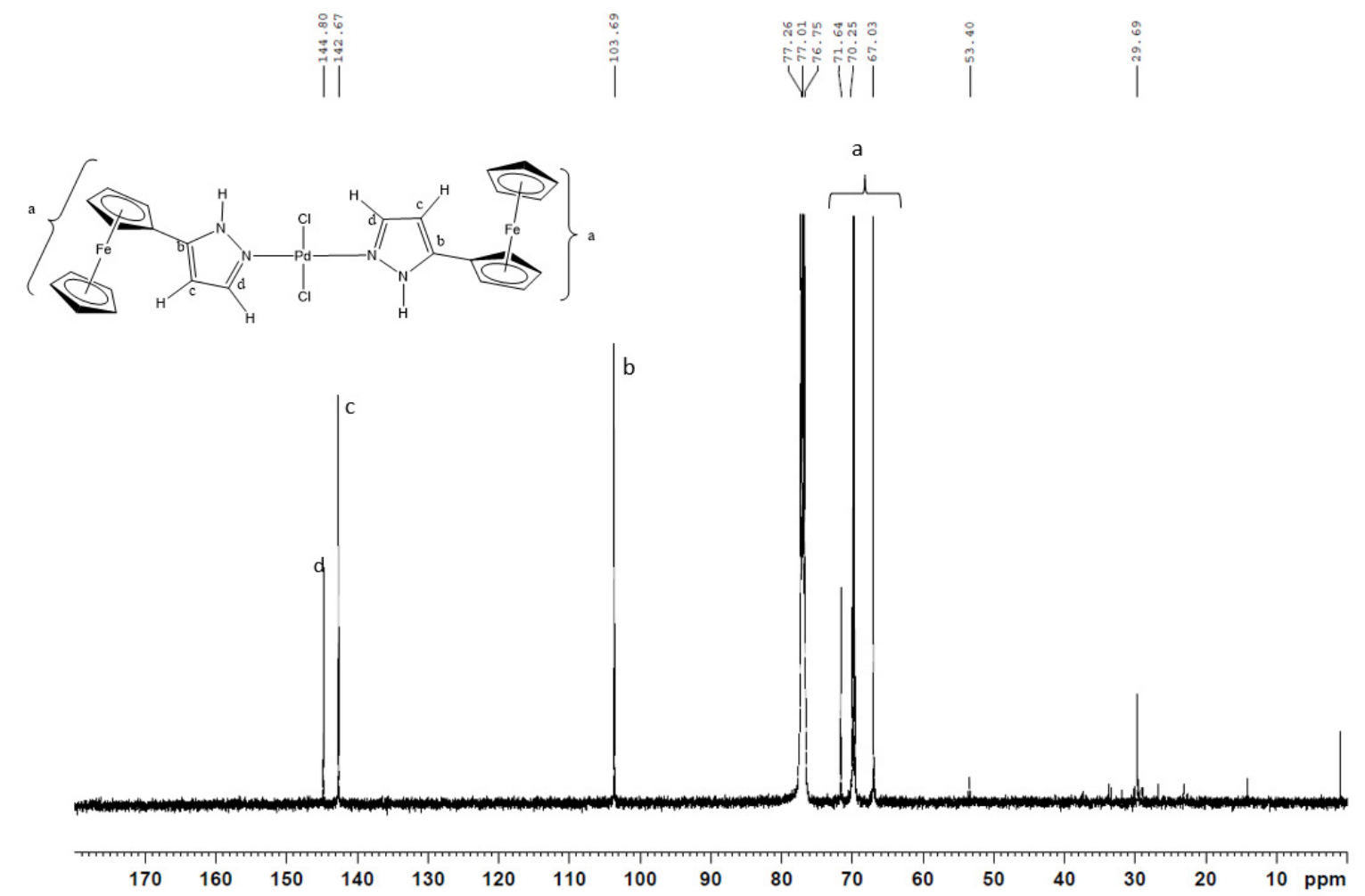

Figure S1-13. ${ }^{13} \mathrm{C}\left\{{ }^{1} \mathrm{H}\right\}$ NMR spectrum of $\mathbf{3}$ recorded in $\mathrm{CDCl}_{3}$ 